\title{
Appraisal of long term groundwater quality of peninsular India using water quality index and fractal dimension
}

\author{
Kishan Singh Rawat ${ }^{1, *}{ }_{(\mathbb{D})}$, Sudhir Kumar Singh ${ }^{2}$, T German Amali Jacintha ${ }^{1}$, \\ JASNA NemČić-JureC ${ }^{3}$ and Vinod Kumar Tripathi ${ }^{4}$ \\ ${ }^{1}$ Centre for Remote Sensing and Geo-Informatics, Sathyabama University, Chennai 600 119, India. \\ ${ }^{2}$ K. Banerjee Centre of Atmospheric and Ocean Studies, IIDS, Nehru Science Centre, University of Allahabad, \\ Allahabad 211 002, India. \\ ${ }^{3}$ Institute of Public Health of Koprivnica-Krizevci, County Trg Tomislava Bardeka 10/10, \\ 48000 Koprivnica, Croatia. \\ ${ }^{4}$ Department of Farm Engineering, Institute of Agricultural Sciences, Banaras Hindu University, Varanasi \\ 221005 , India. \\ *Corresponding author.e-mail:ksr.kishan@gmail.com
}

MS received 24 September 2016; revised 1 May 2017; accepted 7 June 2017; published online 8 December 2017

A review has been made to understand the hydrogeochemical behaviour of groundwater through statistical analysis of long term water quality data (year 2005-2013). Water Quality Index (WQI), descriptive statistics, Hurst exponent, fractal dimension and predictability index were estimated for each water parameter. WQI results showed that majority of samples fall in moderate category during 20052013, but monitoring site four falls under severe category (water unfit for domestic use). Brownian time series behaviour (a true random walk nature) exists between calcium $\left(\mathrm{Ca}^{2+}\right)$ and electric conductivity (EC); magnesium $\left(\mathrm{Mg}^{2+}\right)$ with EC; sodium $\left(\mathrm{Na}^{+}\right)$with $\mathrm{EC}$; sulphate $\left(\mathrm{SO}_{4}^{2-}\right)$ with EC; total dissolved solids (TDS) with chloride $\left(\mathrm{Cl}^{-}\right)$during pre- (2005-2013) and post- (2006-2013) monsoon season. These parameters have a closer value of Hurst exponent $(H)$ with Brownian time series behaviour condition $(H=0.5)$. The result of times series analysis of water quality data shows a persistent behaviour (a positive autocorrelation) that has played a role between $\mathrm{Cl}^{-}$and $\mathrm{Mg}^{2+}, \mathrm{Cl}^{-}$and $\mathrm{Ca}^{2+}$, $\mathrm{TDS}$ and $\mathrm{Na}^{+}$, TDS and $\mathrm{SO}_{4}^{2-}$, TDS and $\mathrm{Ca}^{2+}$ in pre- and post-monsoon time series because of the higher value of $H(>1)$. Whereas an anti-persistent behaviour (or negative autocorrelation) was found between $\mathrm{Cl}^{-}$and EC, TDS and EC during pre- and post-monsoon due to low value of $H$. The work outline shows that the groundwater of few areas needs treatment before direct consumption, and it also needs to be protected from contamination.

Keywords. Fractal dimension; Hurst exponent; predictability index; water quality index.

\section{Introduction}

In recent decade it was found that many regions of the world's groundwater and surface water is getting polluted due to industrialization, unprecedented population growth, deforestation and extensive agriculture (Singh et al. 2010, 2013a, b; Oişte 2014; Rawat and Tripathi 2015; Nemčić-Jurec al. 2017) and land transformation (Amin et al. 2014) on the quality of drinking water resources (Thakur et al. 
2015). The World Health Organization (WHO) has given standard criteria for drinking water. Water quality of watersheds is studied using hydrochemical data that merge with multiple linear regression (Chenini et al. 2008; Mousavi et al. 2008; Chenini and Khemiri 2009) to know the constituent concentrations. Constituent concentrations can be used by water quality managers for the assessment of current water quality states to water quality standards. Examination of physical properties of groundwater that act as surrogates for constituents of interest also helps in the collection of water quality samples (Vassilis et al. 2001; Carlson and Ecker 2002; Joarder et al. 2008; Psargaonkar et al. 2008; Korashey 2009).

The simple statistical analysis of water quality data of groundwater collected from hand pumps at Moradabad, India, help the drinking water quality status. The conductivity of water was high (Kumar and Sinha 2010). Common people are not aware about these standards. It is also difficult for the authority to make any decision based on these different parameters; to understand the combined effects of those elements present in the water through numerical indices such as Water Quality Index (WQI), in terms of numeric (Singh et al. 2015). Most water quality indices rely on normalizing or standardizing data, parameter by parameter, according to expected concentrations and some interpretation of 'good' vs. 'bad' concentrations. Parameters are often then weighed according to their perceived importance to overall water quality and the index is calculated as the weighted average of all observations of interest (Pesce and Wunderlin 2000; Sargaonkar and Deshpande 2003; Stambuk-Giljanovik 2003; Liou et al. 2004; Tsegaye et al. 2006). Normally, the composite form has a qualitative characteristic. Many researchers have used numerical indices such as water quality index (WQI; Singh et al. 2015), synthetic pollution index (SPI; Gautam et al. 2015), normalized difference dispersal index (NDDI; Rawat et al. 2017a,b), and normalized difference index (NDI; Singh et al. $2013 \mathrm{a}, \mathrm{b})$ to categorize water for different levels of pollution. The WQI is most widely used for classification of water with respect to pollution category. Rawat et al. (2017a) used NDDI to map groundwater quality of Dwarka sub-city at Delhi (National Capital of India). Singh et al. (2013a, b) used NDI with geochemical indicators and GIS to map the fluoride contamination of groundwater in northern India. Singh et al. (2015) modelled groundwater quality over a humid subtropical region using numerical indices, earth observation datasets, and X-ray diffraction technique: A case study of Allahabad district, India.

The concept of water quality to categorize water according to its degree of purity or pollution dated back to year 1848 (Vidyalakshmi et al. 2013; Singh et al. 2015) and has been recognized for its importance to public health in the United Kingdom (Snow 1856). WQI methodology has been developed to provide a numeric value that represents the overall water quality, based on several water quality parameters (Avvannavar and Shrihari 2008; Vasanthavigar et al. 2010; Parmar and Bhardwaj 2013; Singh et al. 2015) and can be used to provide the overall summaries of water quality on a scientific basis (Kaurish and Younos 2007). Many researchers have discussed the importance and applicability of numerical index such as WQI for water characterization (Couillard and Lefebvre 1985; House and Newsome 1989; Smith 1989; Swamee and Tyagi 2000; Bordalo et al. 2001; Sánchez et al. 2007; Singh et al. 2015). For instance, $W Q I$ is a single numeric value that explained the complex information of any water body mainly about water quality. Parmer and Bhardwaj (2013) have applied $W Q I$ and fractal dimension approach to study the water of Harike lake on the confluence of Beas and Sutlej rivers of Punjab (India). Singh et al. (2016) applied the WQI to study the status of Bhopal lake water.

The objective of this study was to evaluate the long term (2006-2013) groundwater quality using the WQI, with reference to the standard recommended by WHO 2006 and to understand the behaviour of ions through fractal dimension analysis and also to explore the relationship using regression equations. Further, in the work, statistical analysis, regression equations, Hurst exponent $(H)$, fractal dimension $(D)$, predictability index $(P I)$ and $W Q I$ have been applied on groundwater quality data for better understanding regarding the hydrogeochemical processes that control the hydrogeochemistry of groundwater of the studied region.

\section{Study area}

Kanchipuram district of Tamil Nadu (India) state, lies between $11^{\circ} 00^{\prime}-12^{\circ} 00^{\prime}$ North latitudes and $77^{\circ} 28^{\prime}-78^{\circ} 50^{\prime}$ East longitudes (northeast coast of Tamil Nadu) and on the banks of the Vegavathi River, a tributary of the Palar River (figure 1). The study area has an average elevation of $83.2 \mathrm{~m}$ 


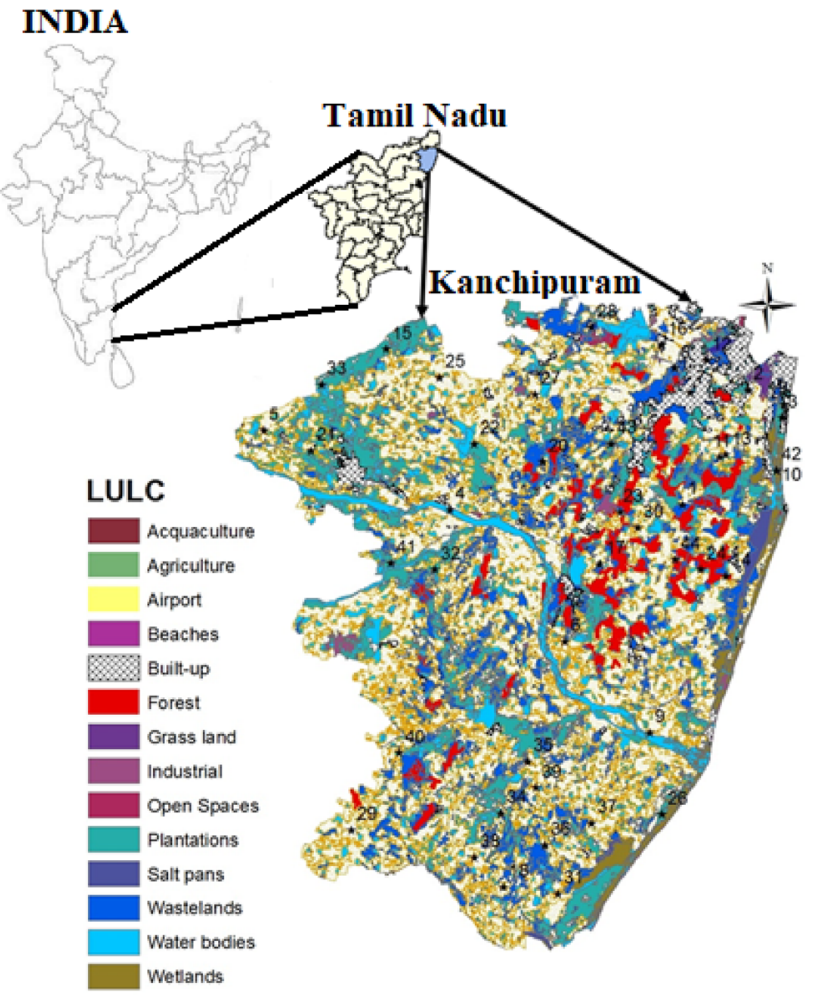

Figure 1. Study area land use/land cover map with 44 sample monitoring points $\left(^{*}\right)$.

above mean sea level, hence flat, and slopes towards the south and east and is bound by Bay of Bengal in the east. Three types of soil (i) clay with some loam, (ii) clay, and (iii) sand are reported in the area (table 1). Agriculture is the main occupation in the region with $47 \%$ of the population engaged in it. Paddy is a major crop in the region, while other crops are groundnut, sugarcane, cereals and millets and pulses (table 1). The total forest area in the district is $426.57 \mathrm{~km}^{2}$ and it is spread in interior regions and around the district. The pre-monsoon rainfall is almost uniform throughout the district. Northeast and southwest monsoon are responsible for rain with $54 \%$ and $36 \%$ contribution each to the total annual rainfall. During normal monsoon, the district receives an average annual rainfall of $1213.3 \mathrm{~mm}$ (table 1 ).

\section{Hydrogeology}

The district is underlain by both sedimentary and fissured formations. The aquifer system of areas are generally constituted by unconsolidated and semi-consolidated formations and weathered, fissured and fractured crystalline rocks.

\subsection{Semi-consolidated, unconsolidated alluvium and fissured formations}

Gondwana sandstones and shales and tertiary mottled clays and sandstones represent the porous, semi-consolidated sediments. Groundwater occurs under water table conditions to confined conditions in inter-granular spaces of sandstones, sands and in the bedding planes and thin fractures of shales, depth of water table ranges from 5 to 10 $\mathrm{m}$ bgl. Unconsolidated formations (alluvium) occur mainly along the banks of Palar and Cheyyar rivers and the sand layers form the potential aquifer. The area lies between Walajabad and Kancheepuram and has small diameter dug wells tap the alluvium with depths ranging between 6 and 12 $\mathrm{m}$ bgl. Some areas are covered by the laterites, where dug wells depth varies from 4 to $6 \mathrm{~m}$ bgl. Along the coast, windblown sand acts as aquifer zones and groundwater extraction is by means of shallow dug wells with radial arms. Principally joints, fissured fractures and their interconnections control the movement of groundwater in fissured crystalline (Balakrishnan 2007).

\section{Materials and method}

\subsection{Laboratory analysis}

The groundwater quality data was acquired from Chennai Water Metro Board/Central Ground Water Board (CGWB) of pre- and post-monsoon season for the period 2005-2013. Out of 44 sampling wells, most of the wells are located near the agricultural fields, while a few are located in the village and town. The collected samples were analyzed by the unit of CGWB, according to APHA guidelines (1996) in the laboratory to measure the cations: Calcium $\left(\mathrm{Ca}^{2+}\right)$, Magnesium $\left(\mathrm{Mg}^{2+}\right)$, Sodium $\left(\mathrm{Na}^{+}\right)$, Potassium $\left(\mathrm{K}^{+}\right)$, anions: Bicarbonate $\left(\mathrm{HCO}_{3}^{-}\right)$, Nitrate $\left(\mathrm{NO}_{3}^{-}\right)$, Chloride $\left(\mathrm{Cl}^{-}\right)$, Fluoride $\left(\mathrm{F}^{-}\right)$, Sulphate $\left(\mathrm{SO}_{4}^{2-}\right)$, Carbon trioxide (Carbonate, $\mathrm{CO}_{3}^{2-}$ ), Total dissolved solids (TDS) and physical parameters as hydrogen ion concentration $(\mathrm{pH})$ and electrical conductivity (EC) in the samples (figure 1).

\subsection{Water quality index}

The WQI was calculated using the standards of drinking water quality recommended by the WHO (2006). Further, the weighted arithmetic index method (Brown et al. 1970) was used for the 
Table 1. General information about study area (source: www.kanchi.tn.nic.in).

\begin{tabular}{ll}
\hline Total area & $4393.37 \mathrm{~km}^{2}$ \\
Net sown area & $1364.89 \mathrm{~km}^{2}$ \\
Net irrigation area & $1236.28 \mathrm{~km}^{2}$ \\
Forest area & $426.57 \mathrm{~km}^{2}$ \\
Poromboke area & $1553.47 \mathrm{~km}^{2}$ \\
Town area & $82.57 \mathrm{~km}^{2}$ \\
Number of Panchayat villages & 648 \\
Summer temperature & $21.1-36.6^{\circ} \mathrm{C}$ \\
Winter temperature & $19.8-28.7^{\circ} \mathrm{C}$ \\
Rainfall & $1133.0 \mathrm{~mm}$ (actual), 1213.3 mm (normal) \\
Major crops & Rice (145966 ha), Sugarcane (7586 ha), Groundnut (28766 ha), Gingelly \\
& $(912$ ha), Pulses (2966 ha), Cotton (53 ha), Millets and Cereals (1217 ha) \\
Soil types & Read loam (Kanchipuram, Uthiramerur Blocks), lateritic soil (Pleatus in \\
& the district), black soil (spread in all blocks), sandy coastal alluvium (Thiru- \\
& porur and St. Thomas Mount) and red sandy soil (Kancheepuram and
\end{tabular}

calculation of $W Q I$ of the surface water. Quality rating or sub-index $\left(Q_{n}\right)$ was calculated using the following expression (1-4).

$$
Q_{n}=100 \times\left[\left(V_{n}-V_{i}\right) /\left(V_{s}-V_{i}\right)\right]
$$

$Q_{n}$ is quality rating for the $n$th water quality parameter, $V_{n}$ is actual value of $n$th parameter, $V_{i}$ is ideal value of this parameter (according WHO2006), and $V_{s}$ is standard permissible value of the $n$th parameter (WHO 2006). (Consider $V_{i}=0$ for all except $\mathrm{pH}$ where $V_{i}=7$ for $\mathrm{pH}$.)

Unit weight was calculated by a value inversely proportional to the recommended standard value $V_{s}$ of the corresponding parameter.

$$
W_{n}=\frac{K}{V_{s}}
$$

and

$$
K=\left[1 / \sum_{n=1}^{n}\left(1 / V_{s}\right)\right]
$$

$W_{n}$ is unit weight for the $n$th parameter, $K$ is constant of proportionality, and $V_{s}$ is standard value for the $n$th parameter.

For computing the WQI, the SI (sub-index) is first to determine for each chemical parameter, which is then used to determine the (WQI) as per the following equation:

$$
S I_{n}=\left(Q_{n}\right)^{W_{n}}
$$

Overall $W Q I$ is calculated taking geometric mean of all sub-indices.

$$
\begin{aligned}
\mathrm{WQI} & =\operatorname{antilog}_{10}\left[\log _{10}(\mathrm{SI})_{\mathrm{n}}\right] \\
& =\operatorname{antilog}_{10}\left[\sum_{n=1}^{i} W_{n} \log _{10} Q_{n}\right]
\end{aligned}
$$

WQI classes are classified on the basis of Brown et al. (1972), Chatterji and Raziuddin (2002) and Singh et al. (2015). According to Brown et al. (1972), Chatterji and Raziuddin (2002) WQI values are rated as excellent $(W Q I<25)$, good $(26<W Q I>50)$, poor $(51<W Q I>75)$, very poor $(76<W Q I>100)$ and unfit for human consumption $(W Q I>100)$ (table $2 \mathrm{~b})$.

\subsection{Statistical analysis}

The statistical data analysis involved in mean, median, mode, standard deviation, kurtosis, skewness, coefficient of variation, regression lines, correlation coefficient, Hurst exponent, fractal dimension and predictability index were calculated for each water quality parameter to understand the variability. The statistical measures, namely, mean explains the average value, median gives the middle values of an ordered sequence or positional average and mode gives the value which occurs the maximum number of times that has the maximum frequency. Standard deviation explains the measure of spread or variability of the sample. The degree of flatness or peakedness in the region about the mode of a frequency curve is defined 
Table 2. (a) Constant of proportionality $(K)$ and unit weight $\left(W_{n}\right)$ for groundwater parameter. (b) Rating and category chart of WQI.

\begin{tabular}{lll}
\hline Parameter & $\begin{array}{c}\text { Standard permissible } \\
\text { value of parameter }\end{array}$ & $\begin{array}{c}\text { Unit weight }\left(W_{n}\right) \\
W_{n}=K / V_{n}\end{array}$ \\
\hline (a) & & \\
$\mathrm{pH}$ & 8.5 & 0.556 \\
$\mathrm{EC}$ & $1400(\mathrm{dS} / \mathrm{m})$ & 0.003 \\
$\mathrm{TDS}$ & $1000(\mathrm{mg} / \mathrm{l})$ & 0.005 \\
$\mathrm{Na}$ & $200(\mathrm{mg} / \mathrm{l})$ & 0.024 \\
$\mathrm{Ca}$ & $75(\mathrm{mg} / \mathrm{l})$ & 0.063 \\
$\mathrm{Mg}$ & $50(\mathrm{mg} / \mathrm{l})$ & 0.094 \\
$\mathrm{~K}$ & $55(\mathrm{mg} / \mathrm{l})$ & 0.086 \\
$\mathrm{Cl}$ & $250(\mathrm{mg} / \mathrm{l})$ & 0.019 \\
$\mathrm{HCO}$ & 0.005 \\
$\mathrm{NO}_{3}^{-}$ & $1000(\mathrm{mg} / \mathrm{l})$ & 0.094 \\
$\mathrm{SO}_{4}^{2-}$ & $50(\mathrm{mg} / \mathrm{l})$ & 0.012 \\
$\mathrm{CO}_{3}^{2-}$ & $400(\mathrm{mg} / \mathrm{l})$ & 0.039 \\
& $120(\mathrm{mg} / \mathrm{l})$ & $\sum W_{n}=1$ \\
(b) & $K=\sum V_{n}=4.72$ & \\
\hline $\mathrm{Sl}^{-} \mathrm{no}^{-}$ & & Water quality status \\
\hline 1 & $\mathrm{WQI}$ & Suitable (excellent) \\
2 & $0-25$ & Slightly polluted (very good) \\
3 & $26-50$ & Moderately polluted (good) \\
4 & $51-75$ & Unfit (very poor) \\
5 & $76-100$ & \\
\hline
\end{tabular}

by Kurtosis. Skewness describes the symmetry of data. Coefficient of variation $(C V)$ gives the relative measure of the sample (Parmer and Bhardwaj 2013).

\subsection{Regression analysis $(R A)$}

Regression analysis is a technique of mathematically sorting (removing) out those variables which does not have any strong statistical relationship between dependent variables and independent variables. Regression line of $Y$ (dependent variable) on $X$ (independent variable) is defined as:

$$
Y=m X+C,
$$

where $m$ is the slope and $C$ is the intercept (the point where the line crosses the y-axis).

Equation (5) represents a linear regression equation of linear line, linear relationship between $X$ and $Y$. The regression coefficient has been calculated using equation (6).

$$
m=r \times S D_{y} / S D_{x}
$$

$m$ is a regression coefficient, $r$ is correlation coefficient, $S D_{y}$ standard deviation of $Y$ series and $S D_{x}$ is standard deviation of $X$ series.

This shows that $r$ is the slope of the regression line of the standardized data points (and that this line passes through the origin). It is sometimes useful to calculate $r_{x y}$ from the data independently using this equation (7):

$$
r_{x y}=\frac{E(X Y)-E(X) E(Y)}{\sqrt{\left(E\left(X^{2}\right)-E(X)^{2}\right)\left(E\left(Y^{2}\right)-E(Y)^{2}\right)}}
$$

where $r_{x, y}$ is correlation coefficient, $E(X Y), E(Y)$, $E(X)$ are the expected value of variables $X Y, Y$ and $X$, respectively.

\subsection{Fractal dimensional analysis (FD)}

The assumption of groundwater quality parameters of a time series can be modeled as a stationary stochastic. We adopted the Rangarajan and Sant (2004) method of mathematical formulation of FD. Stationary stochastic process is considered in discrete time $\left\{\xi_{k}\right\}$, with $\left\langle\xi_{k}\right\rangle=0$ and $\left\{\xi_{k}^{2}\right\}=\sigma^{2}$ where \langle\rangle denotes ensemble average. If the autocorrelation 
function $C(n)=\left\langle\xi_{k} \xi_{k+n}\right\rangle$ scales with the lag $n$ as:

$$
C(n) \sim n^{-\beta}
$$

For large $n$, where $0<\beta<1$, then $\left\{\xi_{k}\right\}$ is called a long memory process. The reason for the latter term is that $C(n)$ decays so slowly that $\sum_{n=1}^{N} C(n)$ diverges as $N \rightarrow \infty$. Most often, long time series exhibits this long memory property. A common method to assess the correlation structure of $\left\{\xi_{k}\right\}$ is to convert the stationary process to a random walk by using partial sums,

$$
\begin{aligned}
& R_{1}=\xi_{k}, \\
& R_{2}=\xi_{1}+\xi_{2}, \\
& \cdots \ldots \ldots . . . \\
& R_{n}=\xi_{1}+\xi_{2}+\ldots+\xi_{n},
\end{aligned}
$$

where $R_{n}$ is the position of the walker at time $n$. The mean range of the random walk trajectory as a function of time bears specific relations with the scaling relation (equation 8). The mean square displacement as a measure of the random walk is considered for analytical evaluation, which is defined as

$$
\begin{aligned}
\left\langle R_{n}^{2}\right\rangle & =\sum_{i=1}^{n}\left\langle R_{i}^{2}\right\rangle+2 \sum_{s=1}^{n-1}(n-s) C(s) \\
& =n \stackrel{2}{\sigma}+2 n \sum_{s=1}^{n-1} C(s)-2 \sum_{s=1}^{n-1} s C(s) .
\end{aligned}
$$

Let $C(s)$ obey the scaling law in equation (8). The sum in the above equation is estimated as:

$$
\sum_{s=1}^{n-1} C(s) \sim \sum_{s=1}^{n} s^{-\beta} \sim \int_{1}^{n} s^{-\beta} \sim n^{1-\beta}
$$

and

$$
\sum_{s=1}^{n-1} s C(s) \sim \sum_{s=1}^{n} s^{1-\beta} \sim \int_{1}^{n} s^{1-\beta} \approx n^{1-\beta} .
$$

For $0<\beta<1$, this means

$$
\left\langle R_{n}^{2}\right\rangle \sim n^{2-\beta} .
$$

for large $n$.

Conventionally, the mean square displacement in characterized by Hurst exponent $(H)$ as equation (9):

$$
\left\langle R_{n}^{2}\right\rangle \sim n^{2 H} \text { (Power law of decay) }
$$

where $H=(2-\beta) / 2$.

\subsection{Hurst exponent $(H)$}

Hurst exponent $(H)$ reveals the index of dependence. It computes the relative tendency of a time series either to regress strongly to the mean or to bunching in a path. The value of $H$ ranges between 0 and 1 . A value of 0.5 indicates a Brownian time series (a true random walk). In a Brownian time series, there is no strong correlation between any element and a future element. A Hurst exponent value, $0.5<H<1$ shows a positive autocorrelation (a persistent behaviour). If there is an increase from time step $t_{i-1}$ to $t_{i}$, there will probably be an increase from $t_{i}$ to $t_{i+1}$. The same is true of decline, where a decline will tend to follow a decline. $H$ value $0<H<0.5$, will exist for a time series with negative autocorrelation (or antipersistent behaviour). Here, raise will tend to be followed by a decline or decline will be followed by raise. This performance is sometimes called mean reversion (Rangarajan and Sant 2004). $H$ can be computed using the following mathematical expression in equation (10)

$$
H=\left|\frac{m-1}{2}\right| .
$$

\subsection{Fractal dimension (D)}

Fractal dimension $(D)$ is a statistical test that provides an indication of how completely a fractal comes into view to fill space, as one zooms to greater and greater scales (Rangarajan and Sant 2004). $H$ is related to $D$ of the time series curve by the following expression by equation (11)

$$
D=2-H \text {. }
$$

If the $D$ for the time series is 1.5 , there is no correlation between variables of two successive time intervals. Therefore, no trend in variables can be distinguished from the time series and therefore the process is unpredictable. But, as the $D$ decreases to 1 , the process becomes more and more predictable as it exhibits persistence. That is, the future trend is more and more likely to follow an established trend (Hsui et al. 1993). D increases from 1.5 to 2 , the process exhibits anti-persistence. Thatis, a 
(a)

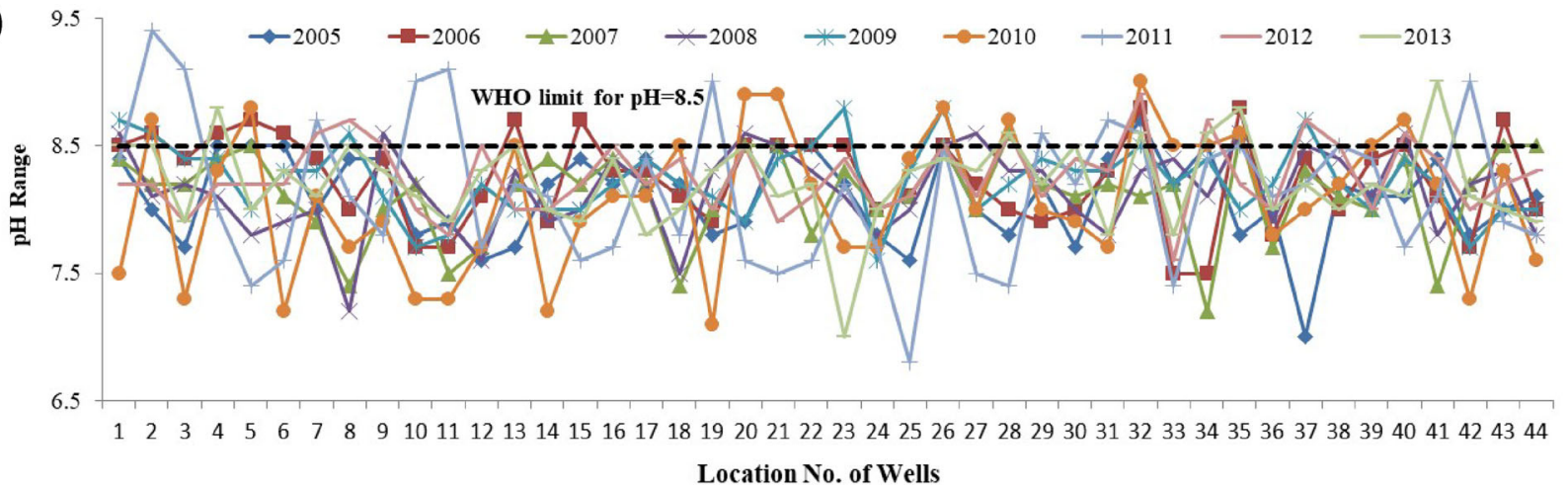

(b)

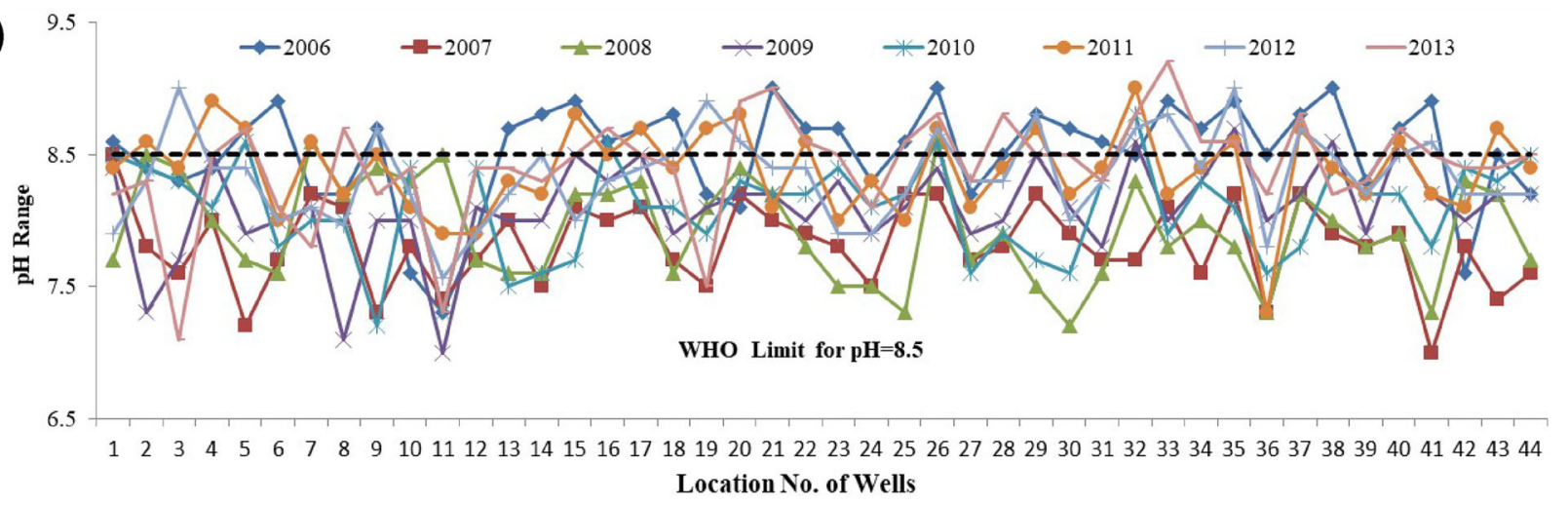

(c)

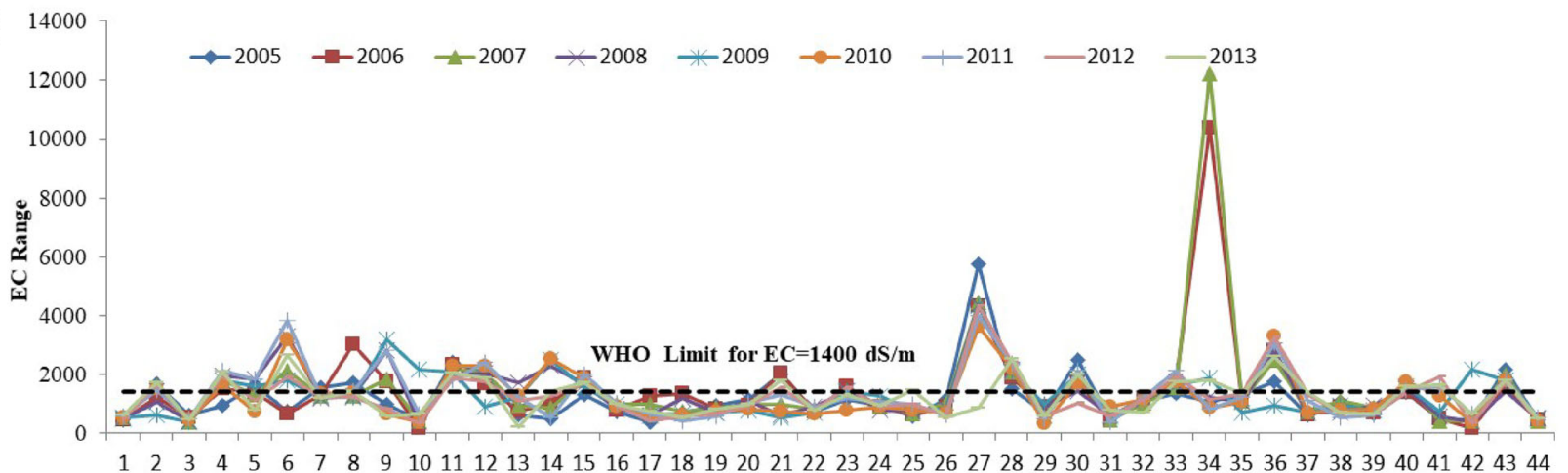

Location No. of wells

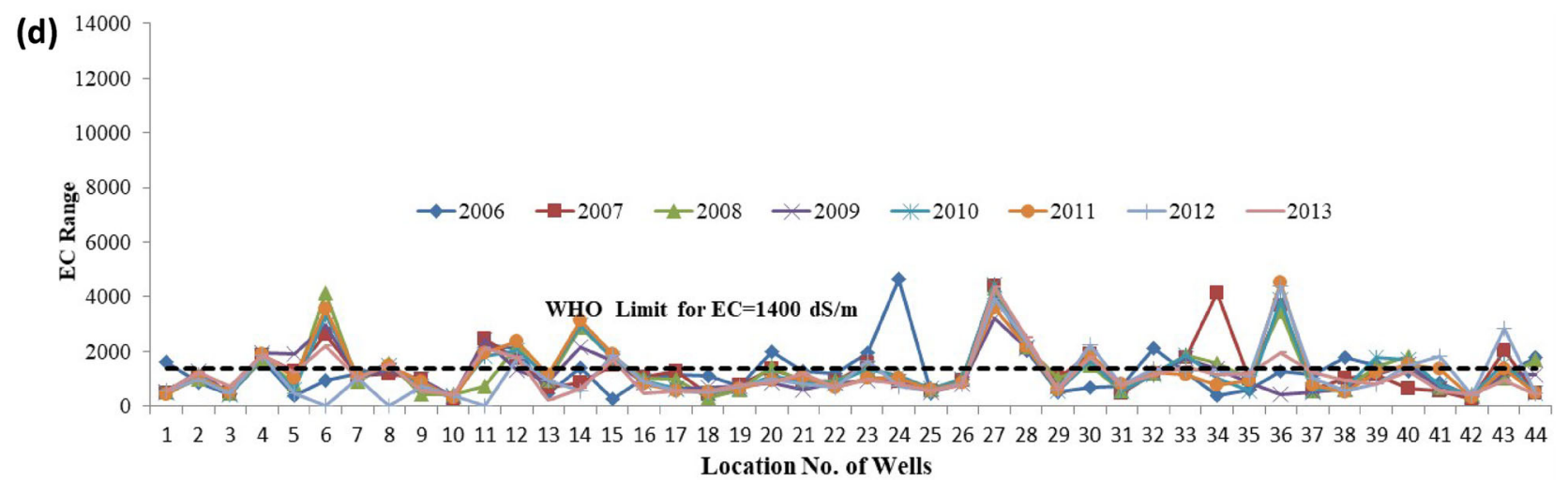

Figure 2. (Continued.) 


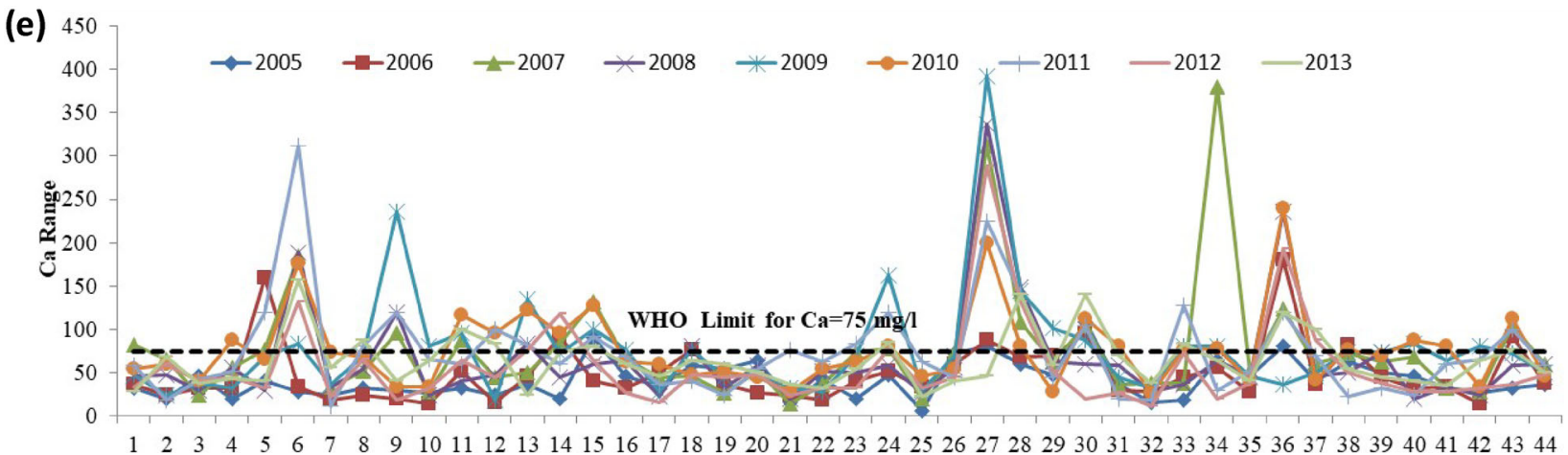

Location No. of Wells
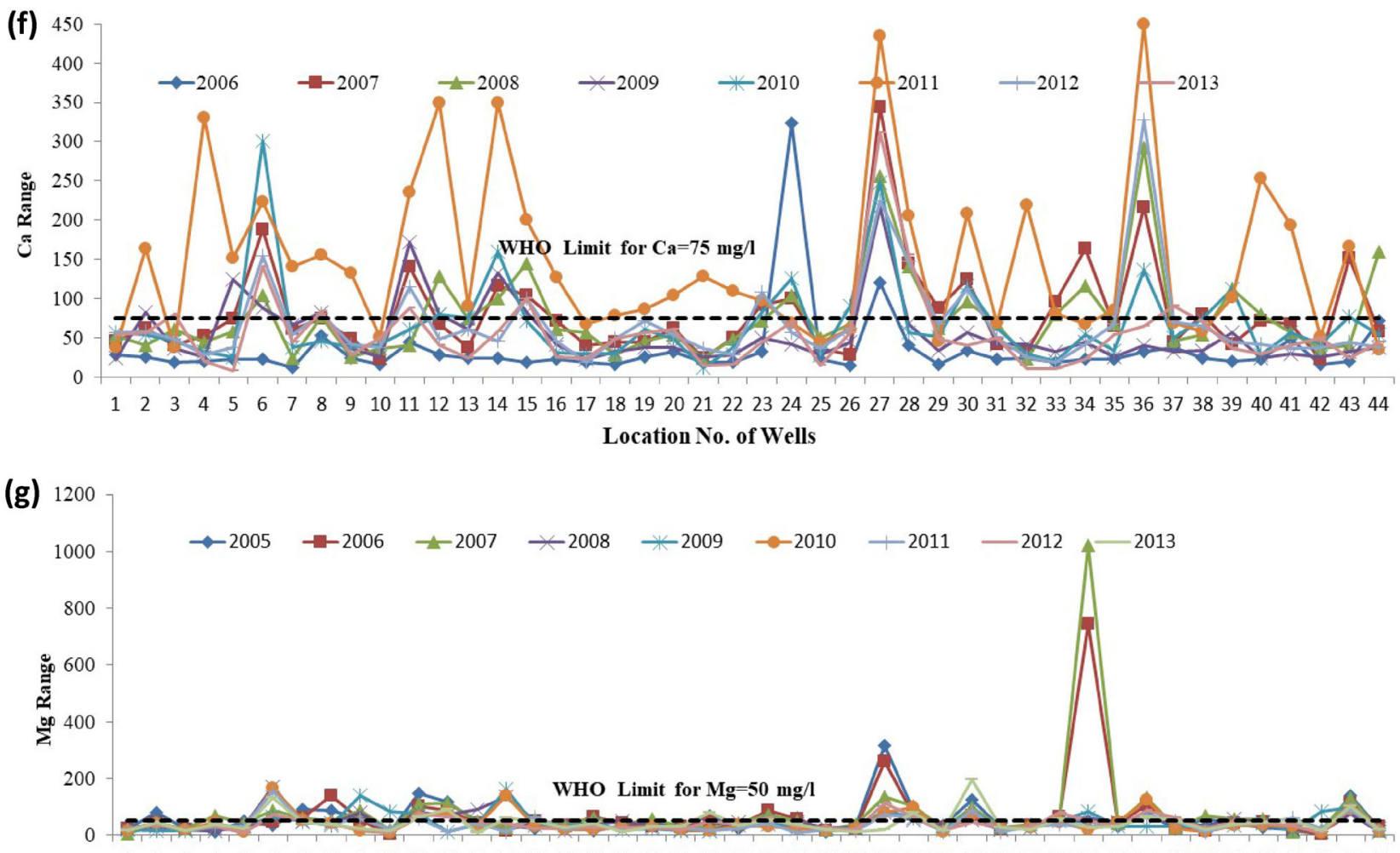

$1 \quad 2 \quad 3 \quad 4 \quad 5 \quad 6 \quad 7 \quad 8 \quad 9 \quad 1011 \quad 121314 \quad 151617 \quad 18192021222324252627282930313233 \quad 3435363738394041424344$ Location No. of Wells

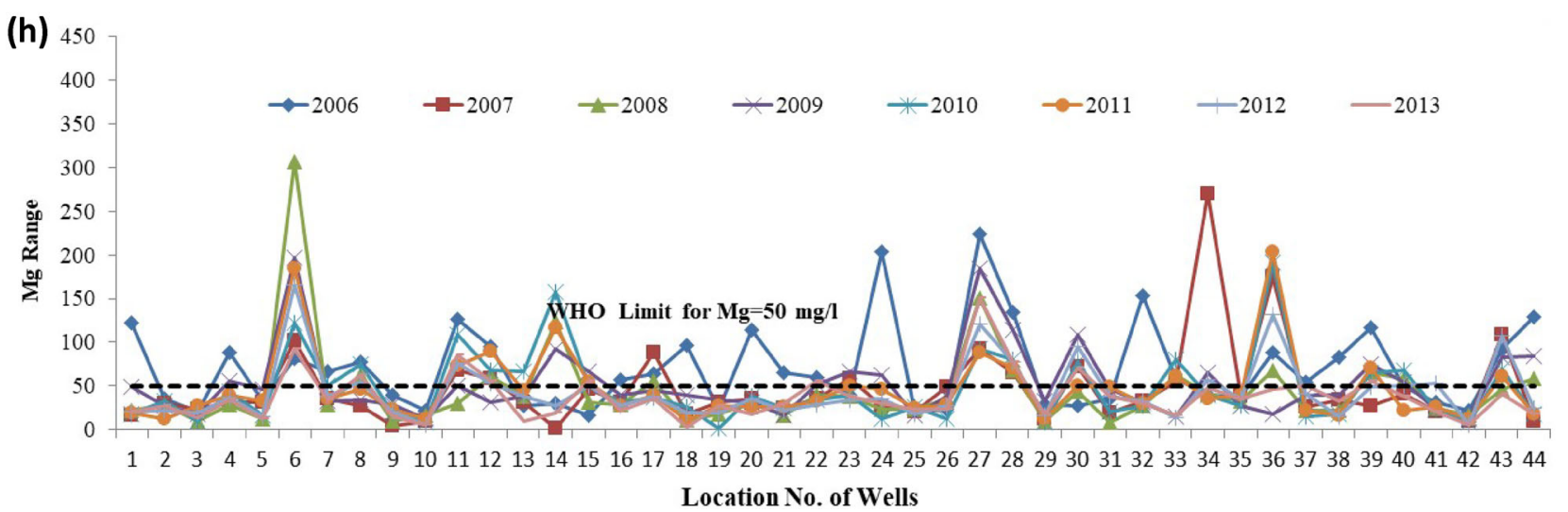

Figure 2. (Continued.) 

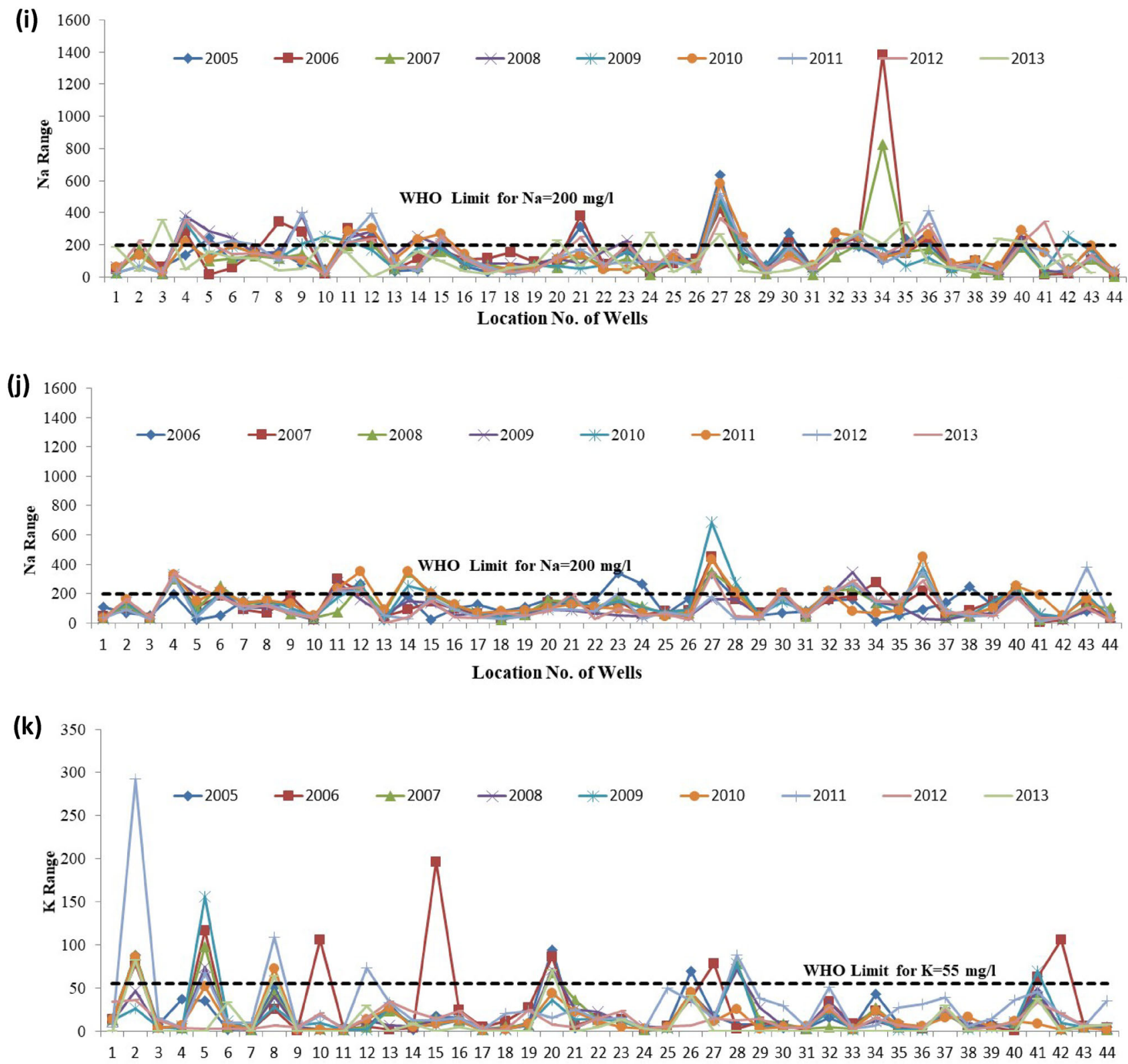

Location No. of Wells

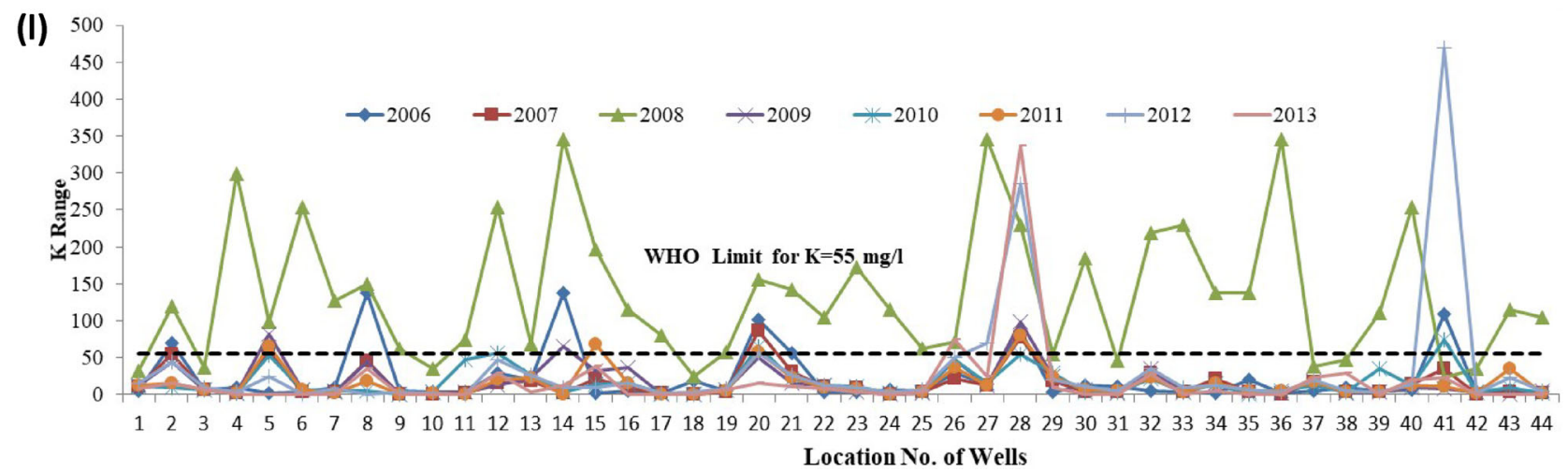

Figure 2. (Continued.) 


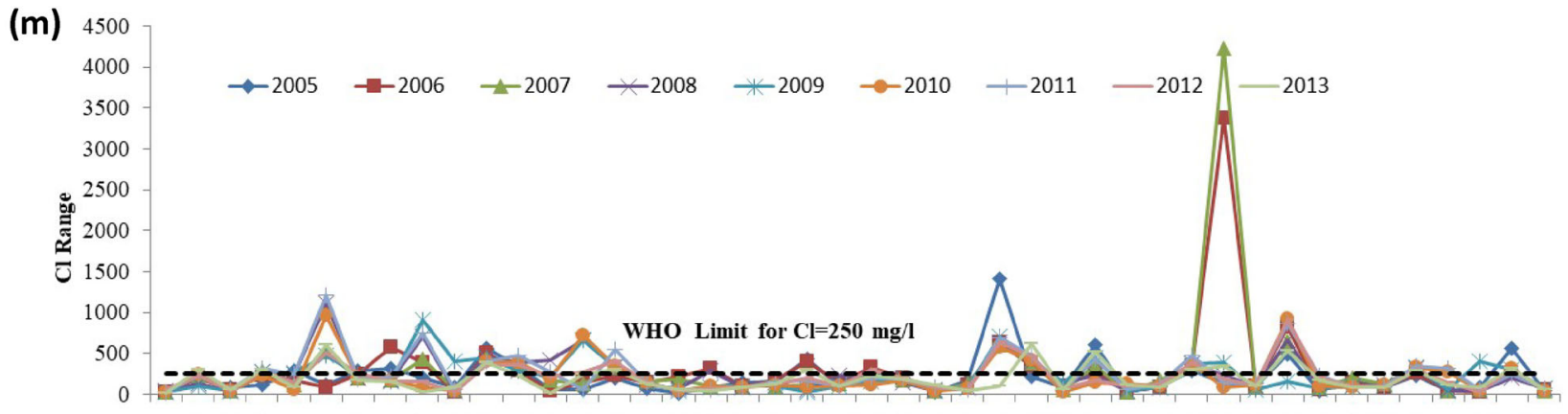

$122 \quad 3 \quad 4 \quad 5 \quad 6 \quad 7 \quad 8 \quad 9 \quad 1011121314151617181920212223242526272829303132333435363738394041424344$ Location No. of Wells

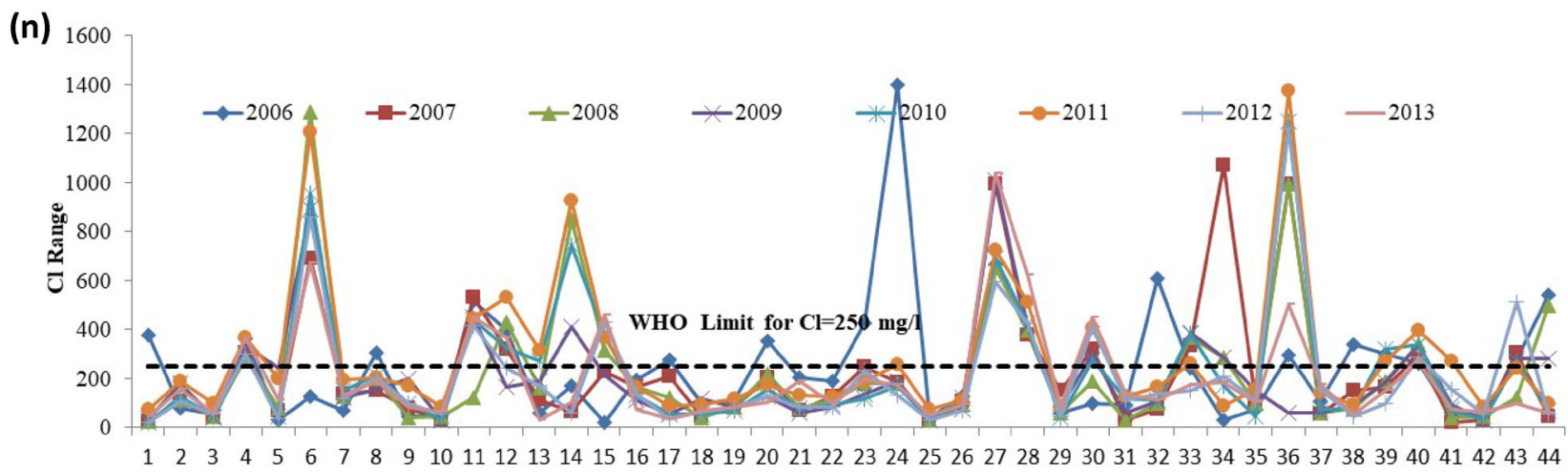
Location No. of Wells

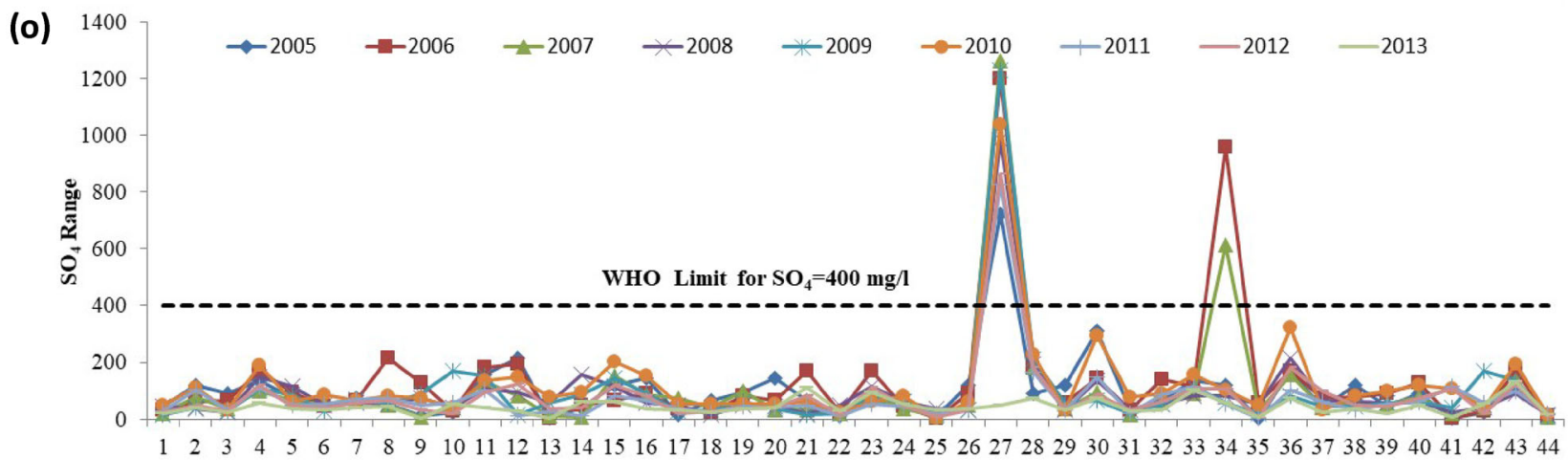

\section{Location No. of Wells}

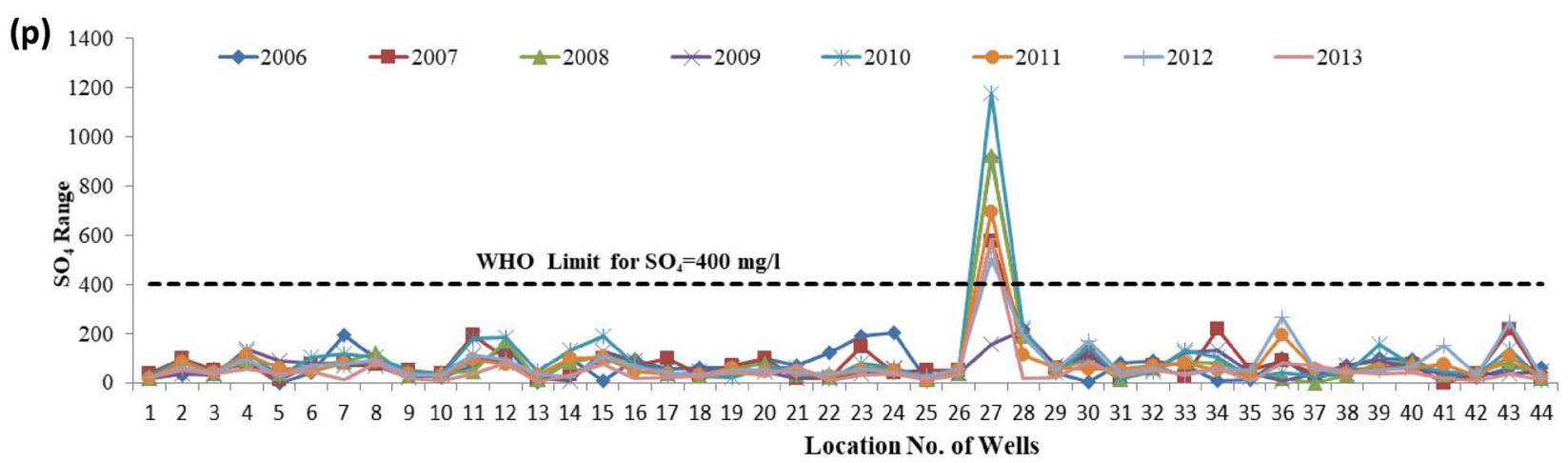

Figure 2. (Continued.) 


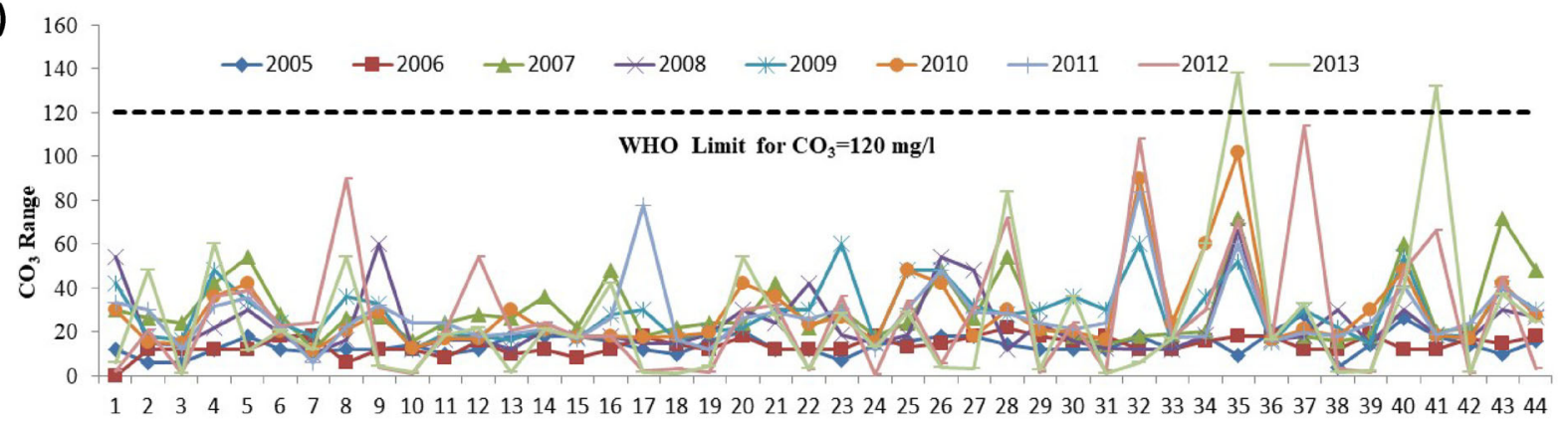

Location No. of Wells

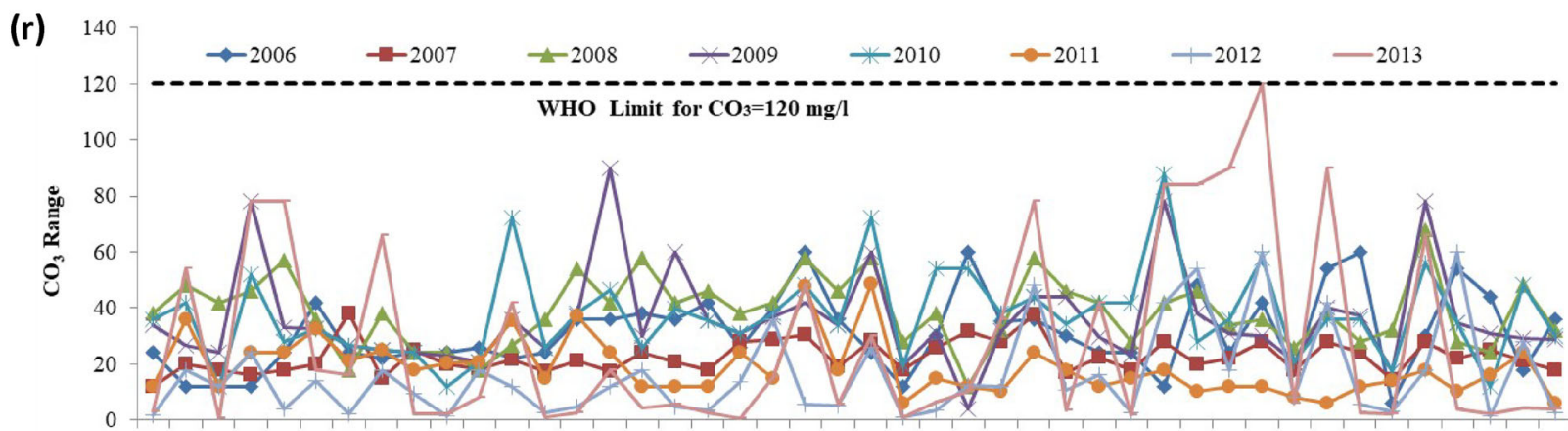

$1 \quad 2 \quad 3 \quad 4 \quad 5 \quad 6 \quad 7 \quad 8 \quad 91011121314151617181920212223242526272829303132333435363738394041424344$ Location No. of Wells

(s)

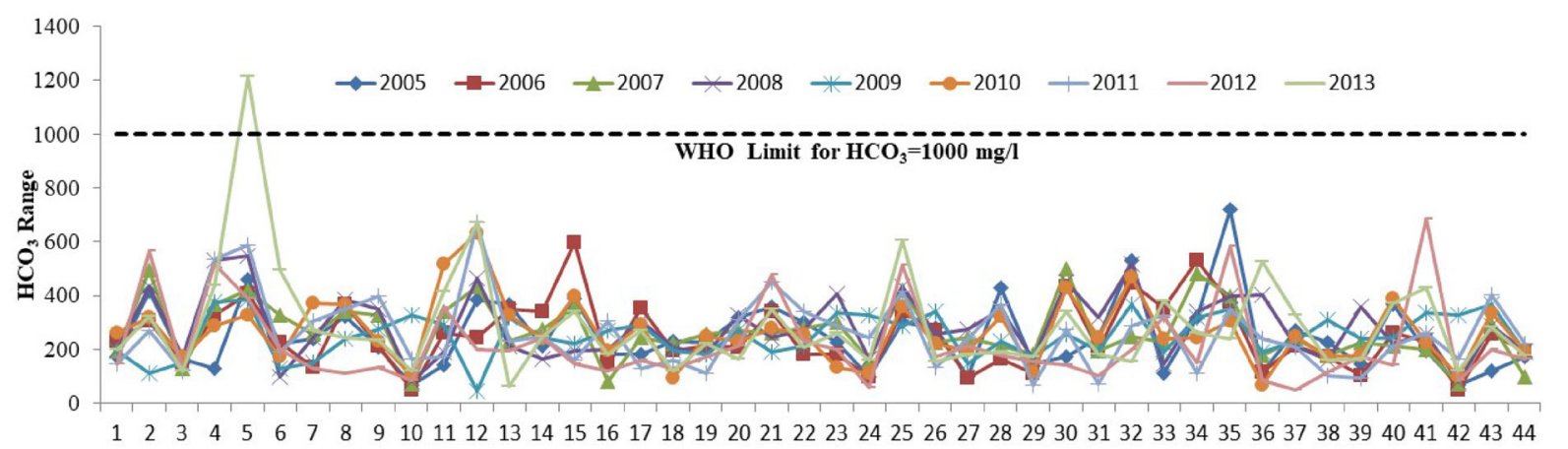

Location No. of Wells

(t)

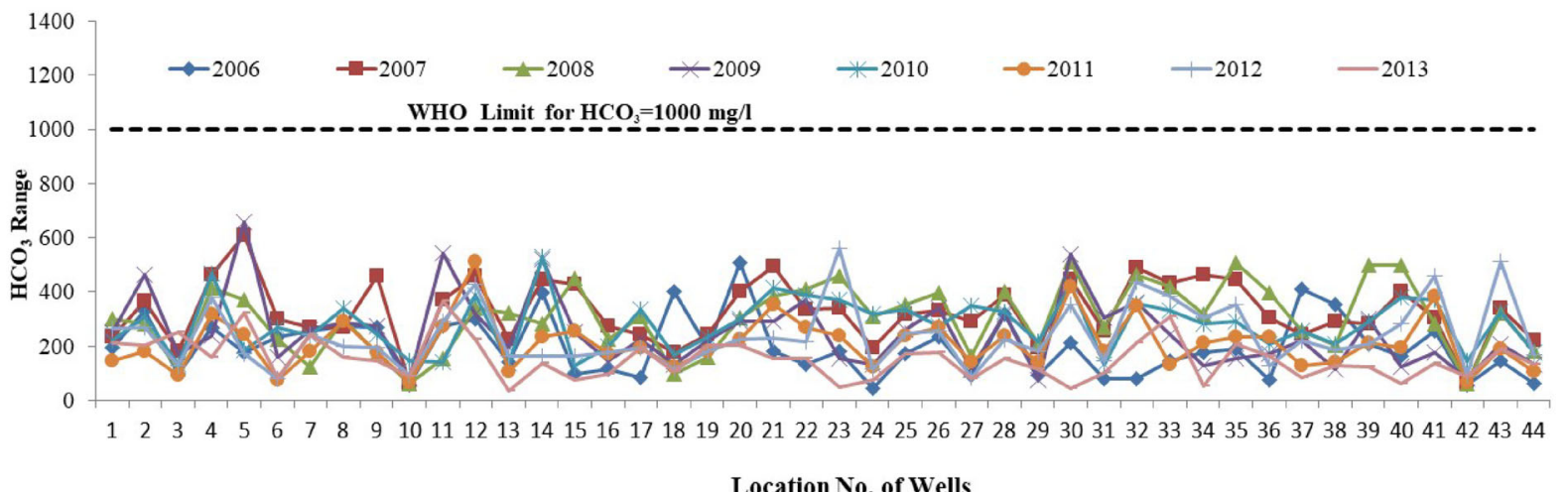

Figure 2. (Continued.) 
(u)

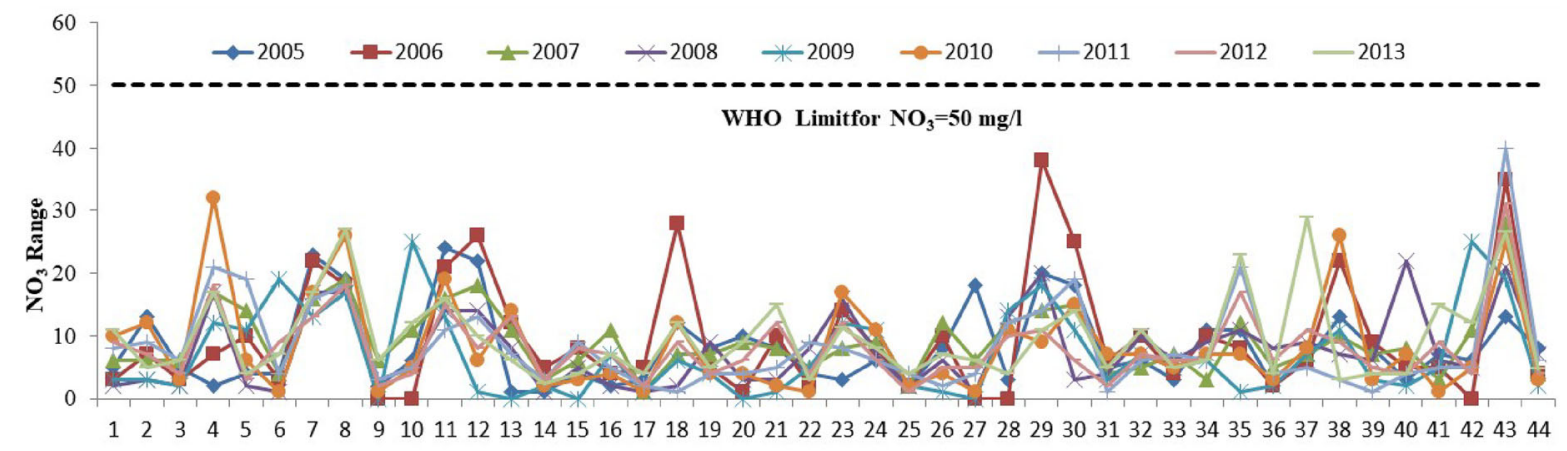
Location No. of Wells

(v)

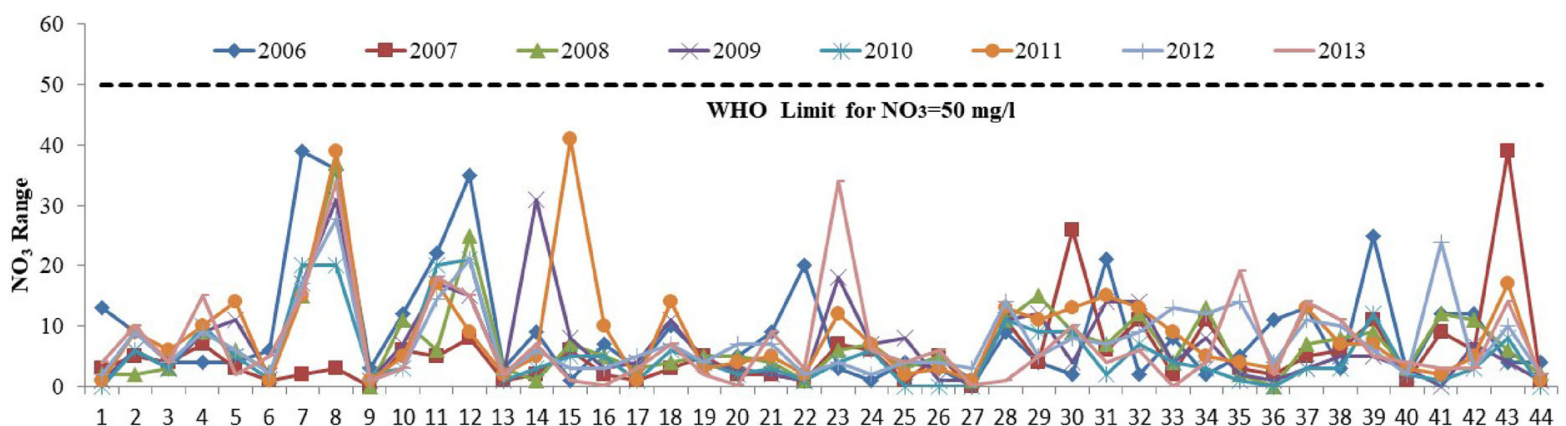

Location No. of Wells

(w)

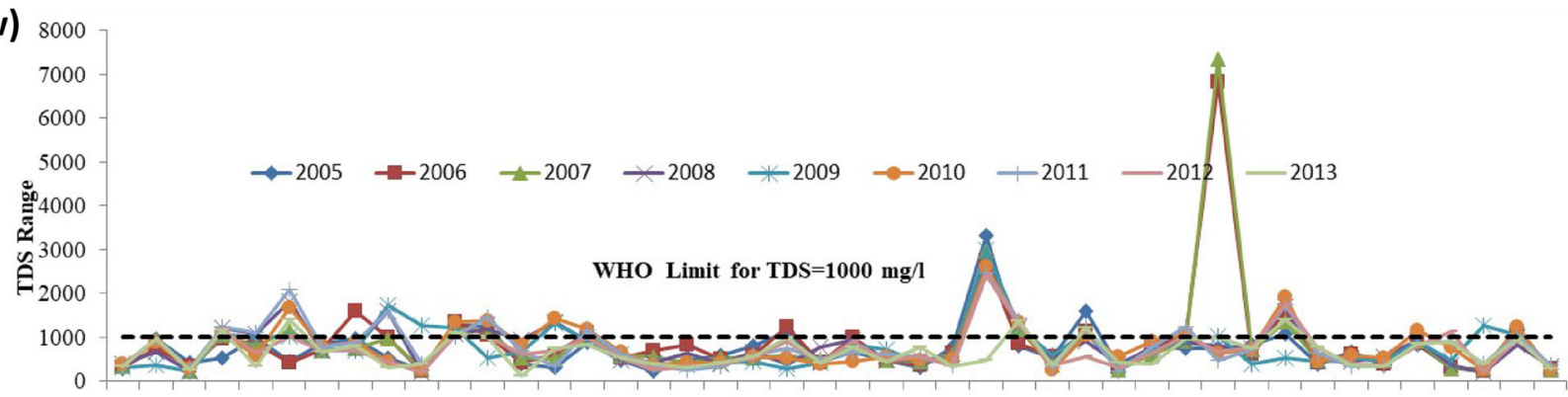

$1 \quad 2 \quad 3 \quad 4 \quad 5 \quad 6 \quad 7 \quad 8 \quad 91011121314151617181920212223242526272829303132333435363738394041424344$ Location No. of Wells

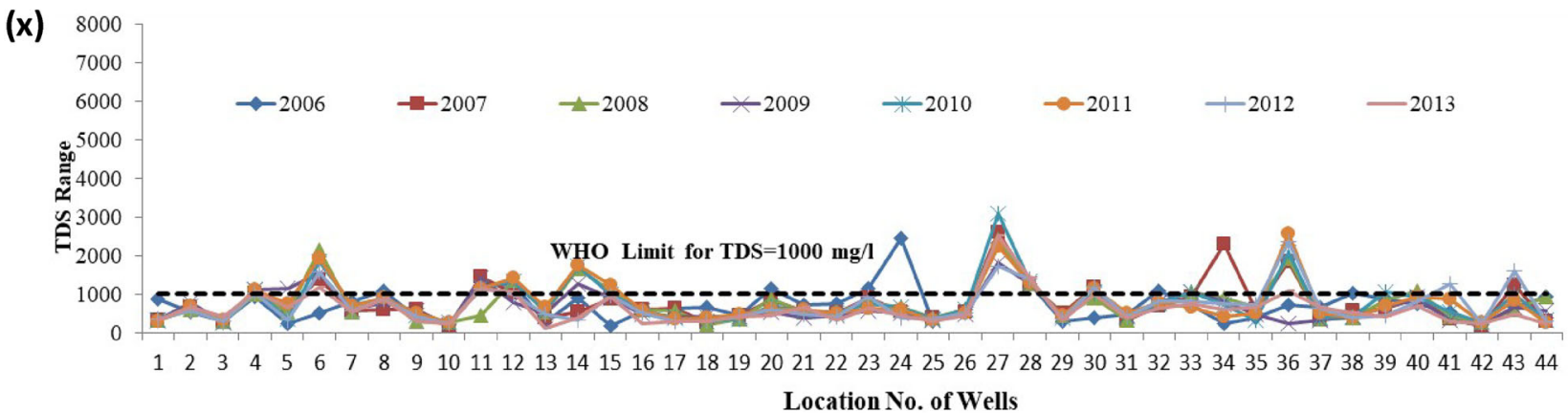

Figure 2. (Continued.) 

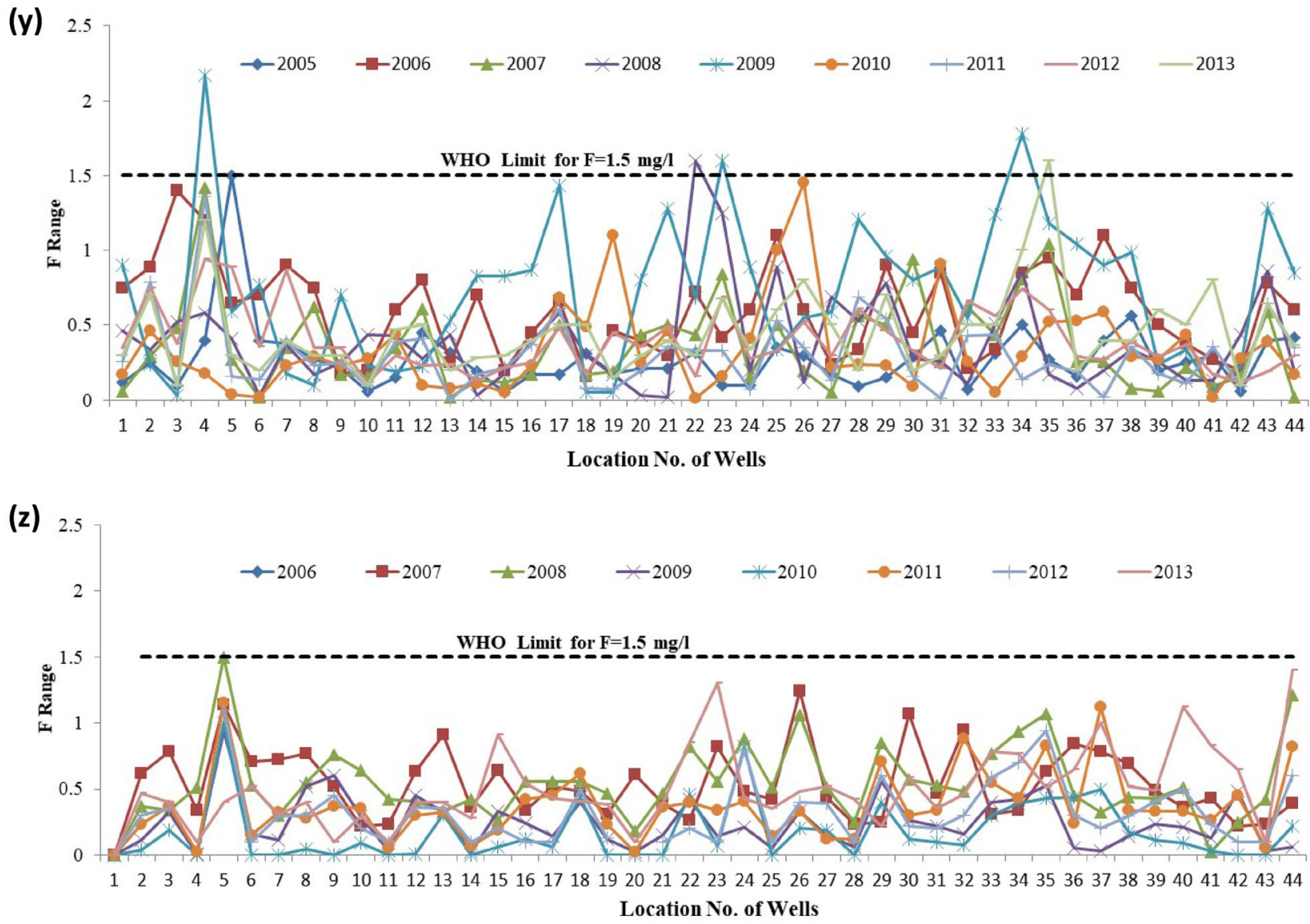

Figure 2. (a) Yearly (2005-2013) value of pre-monsoon pH concentration. (b) Yearly (2006-2013) value of post-monsoon pH concentration. (c) Yearly (2005-2013) value of pre-monsoon EC concentration. (d) Yearly (2006-2013) value of post-monsoon EC concentration. (e) Yearly (2005-2013) value of pre-monsoon Ca concentration. (f) Yearly (2006-2013) value of postmonsoon Ca concentration. (g) Yearly (2005-2013) value of pre-monsoon Mg concentration. (h) Yearly (2006-2013) value of post-monsoon Mg concentration. (i) Yearly (2005-2013) value of pre-monsoon Na concentration. (j) Yearly (2006-2013) value of post-monsoon $\mathrm{Na}$ concentration. (k) Yearly (2005-2013) value of pre-monsoon K concentration. (l) Yearly (20062013) value of post-monsoon K concentration. (m) Yearly (2005-2013) value of pre-monsoon Cl concentration. (n) Yearly (2006-2013) value of post-monsoon $\mathrm{Cl}$ concentration. (o) Yearly (2005-2013) value of pre-monsoon $\mathrm{SO}_{4}^{2-}$ concentration. (p) Yearly (2006-2013) value of post-monsoon $\mathrm{SO}_{4}^{2-}$ concentration. (q) Yearly (2005-2013) value of pre-monsoon $\mathrm{CO}_{3}^{2-}$ concentration. (r) Yearly (2006-2013) value of post-monsoon $\mathrm{CO}_{3}^{2-}$ concentration. (s) Yearly (2005-2013) value of premonsoon $\mathrm{HCO}_{3}^{-}$concentration. (t) Yearly (2006-2013) value of post-monsoon $\mathrm{HCO}_{3}^{-}$concentration. (u) Yearly (2005-2013) value of pre-monsoon $\mathrm{NO}_{3}^{-}$concentration. (v) Yearly (2006-2013) value of post-monsoon $\mathrm{NO}_{3}^{-}$concentration. (w) Yearly (2005-2013) value of pre-monsoon TDS concentration. (x) Yearly (2006-2013) value of post-monsoon TDS concentration.

decrease in correlation of the process is more likely to lead to an increase in the future. Hence, the predictability again increases. We obtain $D$ of the time series (2006-2013 (pre-monsoon) and 20062013 (post-monsoon)) corresponding to 12 water quality parameters for a fixed 44 locations in the study area.

\subsection{Predictability index (PI)}

Predictability index $(P I)$ explains the behaviour of the time series (Rangarajan 1997). The predictability increases in both the cases as when fractal dimension becomes less than 1.5 persistence behaviour) and greater than 1.5 (anti-persistence behaviour). If one of these indices $(H, D$ and $P I$ ) comes close to 0 , then the corresponding process towards the Brownian motion (unpredictable). Equation is the expression of $P I$.

$$
P I=2|D-1.5|
$$

\section{Results and discussion}

\subsection{Hydrogeochemistry}

Knowledge of groundwater quality of any area is useful in order to achieve the goal of sustainability. 
Data from 44 wells were used to study the groundwater chemistry. The major cation, anions and physical water quality parameters are illustrated in figure $2(\mathrm{a}-\mathrm{z})$.

The physicochemical parameters and total cation/anion concentrations of groundwater (GW) at the study area for pre-monsoon for the period 2005-2013 are shown in table 3. EC varied from 180 to $12,240 \mathrm{dS} / \mathrm{m}$ with a mean of $1322.90 \mathrm{dS} / \mathrm{m}$. The range, mean and $S D$ of $\mathrm{pH}$ are $6.80-8.6,8.37$ and 3.20. The mean cation levels in GW followed a descending order as: $\mathrm{Na}^{+}>\mathrm{Ca}^{2+}>\mathrm{Mg}^{2+}>\mathrm{K}^{+}$, $140.54,64.31,50.26$ and $18.46 \mathrm{mg} / \mathrm{l}$, respectively. Similarly, in case of anions, the mean levels in GW followed a descending order as: $\mathrm{HCO}_{3}^{-}>\mathrm{Cl}^{-}>$ $\mathrm{SO}_{4}^{2-}>\mathrm{CO}_{3}^{2-}>\mathrm{NO}_{3}^{-}>\mathrm{F}^{-}, 259.78,236.10,92.55$, 24.468 .42 and $0.43 \mathrm{mg} / \mathrm{l}$, respectively. Mean concentration value of $\mathrm{pH}, \mathrm{EC}, \mathrm{Ca}^{2+}, \mathrm{Na}^{+}, \mathrm{K}^{+}, \mathrm{Cl}^{-}$, $\mathrm{SO}_{4}^{2-}, \mathrm{CO}_{3}^{2-}, \mathrm{HCO}_{3}^{-}, \mathrm{NO}_{3}^{-}$and $\mathrm{F}^{-}$are below the maximum acceptable limits (MAC)/WHO values during pre-monsoon years (2005-2013). The mean concentration value of $\mathrm{Mg}^{2+}(50.26 \mathrm{mg} / \mathrm{l})$ in premonsoon is higher than the MAC/WHO of $50 \mathrm{mg} / 1$ (figure 2a).

The mean levels of all the parameters used in this study during post-monsoon years (2006-2013) can be seen in table 3 together with their respective MAC/WHO values taken from the WHO2006. The results of the descriptive statistics test revealed that there were no statistically significant differences between the mean levels of the parameter values between June (pre-monsoon) and January (post-monsoon). The mean value of $\mathrm{K}$ of post-monsoon shows slight increase as 0.93 $\mathrm{mg} / \mathrm{l}$ compared to pre-monsoon value of $\mathrm{K}$ (18.46 $\mathrm{mg} / \mathrm{l})$. The mean cation levels in GW followed a descending order as: $\mathrm{Na}^{+}(125.56 \mathrm{mg} / \mathrm{l})>\mathrm{Ca}^{2+}$ $(62.74 \mathrm{mg} / \mathrm{l})>\mathrm{Mg}^{2+}(47.93 \mathrm{mg} / \mathrm{l})>\mathrm{K}^{+}(19.39$ $\mathrm{mg} / \mathrm{l})$. In the same manner for anions, the mean levels in GW during post-monsoon years (20062013) followed a descending order as: $\mathrm{HCO}_{3}^{-}>$ $\mathrm{Cl}^{-}>\mathrm{SO}_{4}^{2-}>\mathrm{CO}_{3}^{2-}>\mathrm{NO}_{3}^{-}>\mathrm{F}^{-}, 244.94$, $223.54,76.04,28.70,7.15$ and $0.39 \mathrm{mg} / \mathrm{l}$, respectively (figure $2 \mathrm{~b}$ ). The mean levels of $\mathrm{pH}$ ranged between $8.37 \pm 0.40$ at pre-monsoon and $8.20 \pm$ 0.43 at post-monsoon (table 3 ), reflecting acidic waters.

\subsection{WQI interpretation}

$W Q I$ computed values are given in table $4(\mathrm{a}-\mathrm{b})$ and for better visualization, these values are illustrated

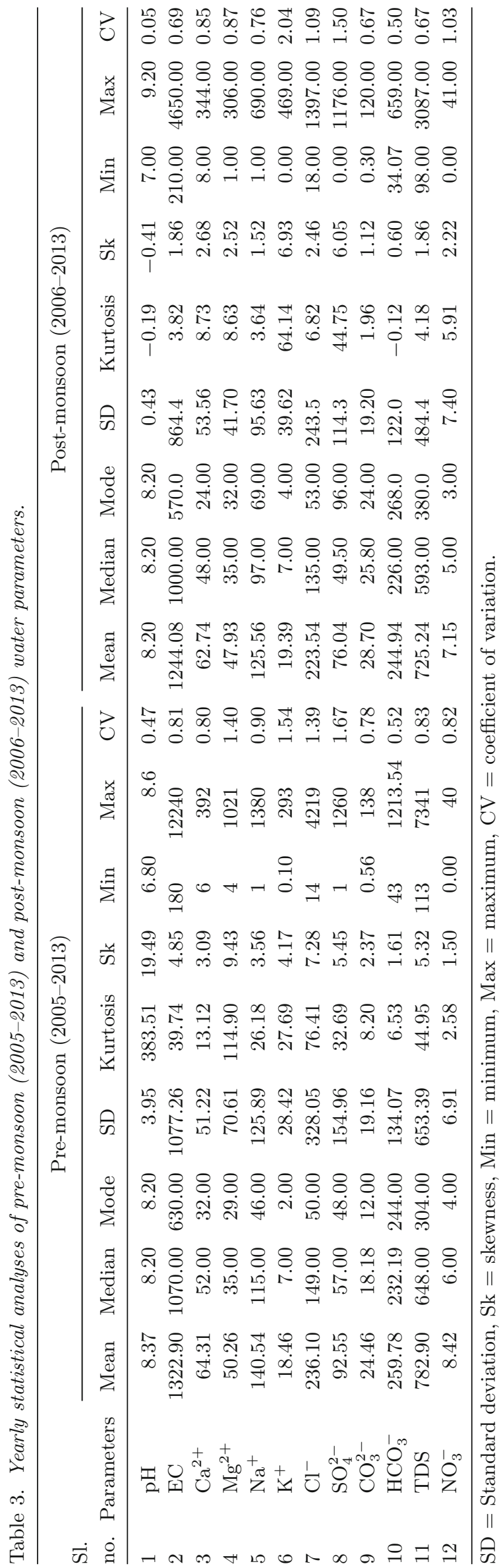


Table 4(a). Yearly (2005-2013) value of pre-monsoon water quality index.

\begin{tabular}{|c|c|c|c|c|c|c|c|c|c|}
\hline Sl. no. & $W Q I_{2005}$ & $W Q I_{2006}$ & $W Q I_{2007}$ & $W Q I_{2008}$ & $W Q I_{2009}$ & $W Q I_{2010}$ & $W Q I_{2011}$ & $W Q I_{2012}$ & $W Q I_{2013}$ \\
\hline 1 & 8.97 & 40.76 & 6.19 & 26.58 & 48.69 & 12.04 & 16.53 & 21.37 & 17.36 \\
\hline 2 & 21.80 & 51.72 & 23.53 & 22.40 & 15.16 & 31.39 & 54.64 & 44.19 & 43.97 \\
\hline 3 & 8.13 & 73.22 & 26.72 & 28.37 & 3.65 & 15.48 & 7.38 & 21.76 & 7.14 \\
\hline 4 & 23.53 & 64.79 & 78.88 & 34.38 & 114.57 & 16.37 & 74.83 & 53.09 & 66.56 \\
\hline 5 & 82.23 & 43.37 & 22.59 & 27.50 & 40.64 & 7.02 & 16.93 & 47.78 & 17.94 \\
\hline 6 & 23.32 & 39.05 & 10.97 & 16.71 & 46.85 & 15.40 & 24.63 & 26.43 & 22.97 \\
\hline 7 & 26.39 & 50.91 & 23.08 & 23.47 & 14.05 & 17.55 & 24.36 & 48.92 & 25.14 \\
\hline 8 & 23.06 & 49.34 & 38.30 & 14.94 & 11.00 & 23.01 & 21.20 & 22.50 & 23.64 \\
\hline 9 & 14.96 & 13.98 & 16.58 & 22.35 & 49.80 & 14.04 & 21.17 & 19.88 & 17.59 \\
\hline 10 & 5.00 & 14.83 & 10.56 & 24.00 & 20.57 & 15.97 & 8.38 & 8.17 & 8.09 \\
\hline 11 & 18.26 & 39.37 & 27.24 & 28.84 & 17.68 & 30.70 & 26.30 & 22.45 & 31.29 \\
\hline 12 & 31.66 & 47.87 & 39.83 & 21.64 & 13.63 & 13.60 & 29.29 & 18.60 & 34.01 \\
\hline 13 & 20.67 & 16.55 & 6.57 & 30.25 & 33.23 & 11.03 & 6.31 & 17.80 & 11.38 \\
\hline 14 & 12.20 & 39.24 & 10.85 & 11.41 & 53.55 & 16.77 & 11.50 & 12.90 & 21.05 \\
\hline 15 & 7.72 & 22.27 & 13.77 & 14.93 & 47.53 & 8.92 & 18.91 & 16.40 & 20.64 \\
\hline 16 & 12.39 & 26.94 & 13.57 & 23.20 & 48.83 & 15.53 & 22.79 & 16.54 & 24.17 \\
\hline 17 & 10.63 & 38.93 & 30.02 & 32.39 & 75.55 & 37.06 & 34.16 & 26.40 & 28.75 \\
\hline 18 & 19.60 & 14.52 & 12.52 & 20.36 & 5.77 & 28.23 & 6.93 & 11.66 & 28.04 \\
\hline 19 & 13.85 & 27.38 & 14.10 & 11.92 & 5.67 & 59.31 & 6.83 & 26.42 & 10.96 \\
\hline 20 & 18.48 & 26.27 & 28.35 & 7.57 & 44.30 & 17.31 & 14.27 & 21.72 & 21.72 \\
\hline 21 & 16.68 & 20.83 & 29.63 & 3.86 & 67.29 & 26.54 & 22.92 & 30.01 & 26.96 \\
\hline 22 & 19.60 & 39.81 & 26.48 & 86.79 & 38.05 & 4.29 & 20.74 & 11.74 & 18.33 \\
\hline 23 & 9.38 & 28.89 & 49.45 & 68.70 & 87.15 & 12.49 & 22.30 & 41.48 & 39.77 \\
\hline 24 & 9.88 & 35.13 & 13.16 & 14.55 & 50.86 & 24.91 & 7.61 & 18.16 & 22.30 \\
\hline 25 & 19.31 & 58.04 & 27.72 & 47.81 & 20.25 & 53.54 & 32.80 & 19.90 & 33.40 \\
\hline 26 & 22.22 & 35.47 & 16.63 & 11.36 & 33.01 & 78.34 & 21.51 & 29.05 & 44.04 \\
\hline 27 & 31.90 & 32.62 & 20.12 & 50.24 & 46.75 & 23.38 & 19.30 & 24.68 & 28.16 \\
\hline 28 & 11.33 & 23.40 & 40.56 & 37.37 & 72.36 & 21.84 & 46.75 & 40.03 & 19.75 \\
\hline 29 & 12.01 & 50.95 & 29.16 & 45.04 & 53.48 & 13.75 & 31.25 & 26.48 & 38.19 \\
\hline 30 & 26.05 & 30.83 & 56.76 & 19.63 & 48.90 & 12.23 & 18.09 & 20.69 & 24.12 \\
\hline 31 & 26.05 & 45.26 & 15.74 & 16.14 & 47.81 & 50.27 & 2.25 & 13.13 & 18.54 \\
\hline 32 & 7.32 & 15.61 & 35.39 & 10.27 & 32.26 & 18.18 & 27.52 & 38.01 & 28.05 \\
\hline 33 & 19.86 & 23.31 & 27.95 & 31.18 & 68.68 & 8.49 & 29.24 & 35.48 & 31.39 \\
\hline 34 & 32.00 & 91.61 & 108.58 & 49.67 & 98.17 & 19.54 & 10.41 & 42.24 & 55.64 \\
\hline 35 & 18.10 & 52.17 & 57.75 & 13.64 & 62.99 & 31.63 & 18.11 & 35.25 & 86.29 \\
\hline 36 & 15.35 & 46.83 & 24.33 & 15.31 & 55.96 & 41.02 & 20.08 & 26.25 & 18.13 \\
\hline 37 & 28.93 & 59.56 & 17.32 & 14.35 & 49.85 & 33.43 & 7.36 & 21.36 & 28.19 \\
\hline 38 & 33.77 & 42.47 & 9.99 & 21.20 & 54.31 & 19.44 & 20.28 & 22.86 & 22.83 \\
\hline 39 & 14.13 & 29.15 & 8.10 & 18.32 & 16.21 & 17.76 & 12.76 & 18.40 & 33.61 \\
\hline 40 & 16.74 & 23.67 & 17.73 & 12.33 & 23.09 & 28.67 & 11.38 & 23.60 & 30.10 \\
\hline 41 & 19.10 & 18.04 & 7.78 & 10.83 & 8.01 & 5.84 & 25.68 & 13.61 & 47.77 \\
\hline 42 & 5.00 & 14.89 & 10.61 & 24.04 & 20.61 & 16.01 & 8.38 & 8.17 & 8.09 \\
\hline 43 & 30.15 & 49.56 & 41.26 & 50.62 & 73.42 & 29.30 & 42.13 & 18.56 & 45.21 \\
\hline 44 & 23.98 & 33.21 & 3.83 & 12.45 & 45.83 & 10.92 & 21.84 & 17.89 & 21.72 \\
\hline Max & 82.23 & 91.61 & 108.58 & 86.79 & 114.57 & 78.34 & 74.83 & 53.09 & 86.29 \\
\hline Min & 5 & 13.98 & 3.83 & 3.86 & 3.65 & 4.29 & 2.25 & 8.17 & 7.14 \\
\hline Average & 19.81 & 37.33 & 26.14 & 25.65 & 42.86 & 22.92 & 21.54 & 25.04 & 28.47 \\
\hline $\mathrm{SD}$ & 12.36 & 16.94 & 20.13 & 16.63 & 25.57 & 15.01 & 13.73 & 11.17 & 15.24 \\
\hline
\end{tabular}


Table 4(b). Yearly (2006-2013) value of post-monsoon water quality index.

\begin{tabular}{|c|c|c|c|c|c|c|c|c|c|}
\hline Sl. no. & $W Q I_{2005}$ & $W Q I_{2006}$ & $W Q I_{2007}$ & $W Q I_{2008}$ & $W Q I_{2009}$ & $W Q I_{2010}$ & $W Q I_{2011}$ & $W Q I_{2012}$ & $W Q I_{2013}$ \\
\hline 1 & - & 8.37 & 34.04 & 21.94 & 9.34 & 4.72 & 14.18 & 18.21 & 26.62 \\
\hline 2 & - & 5.85 & 45.30 & 22.36 & 22.27 & 14.07 & 23.01 & 22.81 & 25.11 \\
\hline 3 & - & 2.25 & 19.94 & 28.50 & 2.89 & 2.26 & 4.07 & 2.79 & 8.11 \\
\hline 4 & - & 6.57 & 62.48 & 80.72 & 53.63 & 56.09 & 63.42 & 60.43 & 25.46 \\
\hline 5 & - & 2.62 & 42.02 & 31.74 & 17.94 & 4.21 & 13.77 & 8.06 & 28.89 \\
\hline 6 & - & 5.43 & 47.44 & 35.62 & 19.51 & 15.12 & 33.05 & 26.03 & 25.16 \\
\hline 7 & - & 6.55 & 43.13 & 31.43 & 31.04 & 7.53 & 18.74 & 19.84 & 24.24 \\
\hline 8 & - & 12.82 & 31.80 & 46.53 & 37.71 & 6.91 & 26.26 & 27.00 & 13.99 \\
\hline 9 & - & 3.26 & 13.47 & 34.53 & 17.98 & 7.16 & 20.35 & 12.76 & 16.49 \\
\hline 10 & - & 2.46 & 13.22 & 23.86 & 3.48 & 2.00 & 4.44 & 6.66 & 6.82 \\
\hline 11 & - & 9.91 & 40.59 & 24.13 & 24.88 & 10.97 & 22.94 & 22.24 & 28.59 \\
\hline 12 & - & 9.66 & 52.77 & 26.22 & 21.73 & 25.85 & 25.11 & 25.38 & 27.45 \\
\hline 13 & - & 3.11 & 21.79 & 26.37 & 5.84 & 6.68 & 9.25 & 9.76 & 15.42 \\
\hline 14 & - & 8.87 & 35.70 & 24.46 & 29.29 & 16.68 & 21.28 & 13.28 & 49.39 \\
\hline 15 & - & 1.72 & 23.81 & 35.71 & 20.27 & 12.62 & 32.23 & 11.60 & 35.08 \\
\hline 16 & - & 4.72 & 30.71 & 32.96 & 12.05 & 6.89 & 26.62 & 8.86 & 23.68 \\
\hline 17 & - & 4.86 & 30.23 & 33.27 & 23.89 & 25.47 & 34.21 & 28.11 & 23.32 \\
\hline 18 & - & 6.88 & 18.01 & 25.67 & 9.86 & 2.81 & 14.42 & 9.23 & 21.10 \\
\hline 19 & - & 2.90 & 34.37 & 12.09 & 4.54 & 2.50 & 4.42 & 3.40 & 8.29 \\
\hline 20 & - & 11.73 & 27.27 & 31.88 & 12.87 & 6.51 & 23.64 & 11.17 & 23.10 \\
\hline 21 & - & 7.36 & 17.01 & 45.05 & 24.08 & 26.85 & 24.75 & 13.80 & 47.03 \\
\hline 22 & - & 5.48 & 45.37 & 32.69 & 11.33 & 7.32 & 20.64 & 8.12 & 69.52 \\
\hline 23 & - & 5.09 & 30.92 & 49.90 & 16.72 & 47.03 & 26.15 & 46.27 & 27.18 \\
\hline 24 & - & 20.24 & 25.69 & 30.47 & 7.43 & 4.57 & 12.16 & 8.52 & 21.42 \\
\hline 25 & - & 2.36 & 65.26 & 56.73 & 19.12 & 12.84 & 19.43 & 22.68 & 26.37 \\
\hline 26 & - & 3.97 & 27.03 & 31.55 & 12.55 & 14.97 & 10.98 & 24.84 & 32.03 \\
\hline 27 & - & 16.80 & 27.61 & 28.93 & 19.46 & 14.91 & 18.30 & 20.41 & 39.51 \\
\hline 28 & - & 12.52 & 23.93 & 51.79 & 41.13 & 30.00 & 47.14 & 49.99 & 32.78 \\
\hline 29 & - & 2.57 & 58.19 & 33.38 & 17.68 & 9.71 & 19.28 & 14.67 & 32.70 \\
\hline 30 & - & 3.17 & 32.62 & 32.97 & 19.33 & 13.16 & 24.96 & 19.32 & 24.31 \\
\hline 31 & - & 4.19 & 50.69 & 27.06 & 12.43 & 7.29 & 49.27 & 18.97 & 26.77 \\
\hline 32 & - & 9.74 & 20.56 & 44.08 & 26.11 & 19.97 & 32.36 & 35.13 & 44.00 \\
\hline 33 & - & 5.05 & 23.44 & 53.97 & 25.23 & 26.19 & 27.47 & 39.10 & 42.01 \\
\hline 34 & - & 2.76 & 52.47 & 61.20 & 33.17 & 26.55 & 45.71 & 53.25 & 30.47 \\
\hline 35 & - & 3.91 & 46.80 & 27.04 & 5.56 & 25.11 & 16.16 & 20.42 & 38.22 \\
\hline 36 & - & 6.48 & 55.02 & 28.88 & 3.73 & 41.03 & 75.08 & 27.09 & 56.23 \\
\hline 37 & - & 5.30 & 38.47 & 25.92 & 11.02 & 11.68 & 21.39 & 20.36 & 33.43 \\
\hline 38 & - & 6.88 & 29.28 & 25.02 & 15.26 & 8.87 & 19.52 & 23.83 & 29.73 \\
\hline 39 & - & 8.30 & 22.08 & 32.88 & 16.49 & 13.28 & 22.55 & 29.37 & 60.76 \\
\hline 40 & - & 4.56 & 27.27 & 8.19 & 12.21 & 7.78 & 18.04 & 16.91 & 47.01 \\
\hline 41 & - & 7.89 & 23.85 & 18.02 & 27.01 & 5.91 & 27.87 & 28.21 & 36.06 \\
\hline 42 & - & 2.61 & 13.26 & 23.86 & 3.55 & 2.00 & 4.40 & 6.66 & 6.82 \\
\hline 43 & - & 6.12 & 31.19 & 65.82 & 8.91 & 18.37 & 48.26 & 40.29 & 74.55 \\
\hline 44 & - & 9.44 & 24.47 & 19.55 & 11.98 & 8.66 & 15.39 & 12.63 & 55.75 \\
\hline Max & & 20.24 & 65.26 & 80.72 & 53.63 & 56.09 & 75.08 & 60.43 & 74.55 \\
\hline Min & & 1.72 & 13.22 & 8.19 & 2.89 & 2 & 4.07 & 2.79 & 6.82 \\
\hline Average & & 6.44 & 33.65 & 33.75 & 17.78 & 14.57 & 24.61 & 21.56 & 31.61 \\
\hline $\mathrm{SD}$ & & 3.95 & 13.58 & 14.18 & 10.84 & 12.11 & 14.83 & 13.42 & 15.57 \\
\hline
\end{tabular}


by figure $3(\mathrm{a}-\mathrm{b})$. The maximum average is 42.86 $\left(W Q I_{2009}\right)$ and minimum average $19.81\left(W Q I_{2005}\right)$ for pre-monsoon season compared to maximum average of $33.75\left(W Q I_{2008}\right)$ and minimum average of $6.44\left(W Q I_{2006}\right)$ in the post-monsoon season.

$W Q I$ results show that few wells are also crossing the 4th category (76-100) as highly polluted (poor) (Brown et al. 1972; Chatterjee and Raziuddin 2002): well no. $4\left(W Q I_{\mathrm{Pre} 2008}=78.88\right)$, $5\left(W Q I_{\mathrm{Pre} 2005}=82.23\right), 22\left(W Q I_{\mathrm{Pre} 2008}=86.79\right)$, $23\left(W Q I_{\text {Pre2009 }}=87.15\right), 34\left(W Q I_{\text {Pre2006 }}=91.61\right.$ and $\left.W Q I_{\mathrm{Pre} 2007}=108.58\right)$ and well no. $35\left(W Q I_{\mathrm{Pre} 2013}=86.29\right)$. Well no. 34 shows slight higher yearly fluctuations from 4 th to 5 th category (WQI $>100$, unsuitable/unsafe for drinking) during pre-monsoon period (figure $3 \mathrm{a}$ ). Overall, from the WQI analysis of pre-monsoon (2005-2013), results outline that majority of wells are in category of 1st (excellent) and 2nd (good).

$W Q I$ of post-monsoon period (2006-2013) highlights that 11 wells (well no. $4\left(W Q I_{\text {Post2007 }}=\right.$ $62.48, W Q I_{\text {Post } 2009}=53.63, W Q I_{\text {Post } 2010}=56.09$, $W Q I_{\text {Post2011 }}=63.42$ and $\left.W Q I_{\text {Post2012 }}=60.43\right)$, well no. $12\left(W Q I_{\text {Post2007 }}=52.77\right), 22\left(W Q I_{\text {Post2013 }}\right.$ $=69.52)$, well no. $25\left(W Q I_{\text {Post2007 }}=52.77\right)$, well no. $28\left(W Q I_{\mathrm{Post} 2007}=51.79\right)$, well no. 29 $\left(W Q I_{\text {Post2006 }}=58.19\right)$, well no. $33\left(W Q I_{\text {Post2008 }}=\right.$ $53.97)$, well no. $34\left(W Q I_{\text {Post2007 }}=52.47\right.$, $W Q I_{\mathrm{Post} 2008}=61.2$ and $\left.W Q I_{\mathrm{Post} 2012}=53.25\right)$, well no. $36\left(W Q I_{\text {Post2011 }}=75.08\right.$ and $W Q I_{\text {Post2013 }}$ $=56.23)$, well no. $39\left(W Q I_{\text {Post2013 }}=60.76\right)$, well no. $43\left(W Q I_{\text {Post2013 }}=74.55\right)$ and well no. $44\left(W Q I_{\text {Post2013 }}=55.75\right)$ are lying under the 3rd category $(51<W Q I>75)$ (figure $3 \mathrm{~b}$ ). In postmonsoon, the $W Q I$ shows that well no. 4, has fluctuating behaviour from 3rd to 4th category (very poor, $76<W Q I>100$ ) during 2008. The wells in post-monsoon are also falling in category of 1st (excellent) and 2nd (good). The WQI values generally have low values in the post-monsoon season, which suggest that due to rainfall, the groundwater water table gets recharged, hence the dilution is high. The high values of WQI at these stations have been reported mainly due to higher values of iron, nitrate, total dissolved solids, hardness, fluorides, bicarbonate and manganese in the groundwater.

\subsection{Calcium $\left(\mathrm{Ca}^{2+}\right)$}

Silicate weathering is the dominant process for the supply of calcium ions to the groundwater (figure $3 \mathrm{a})$. In addition to silicate weathering, the carbonate weathering process is also a contributor for increasing of calcium ions in this groundwater. Sodium and calcium ions are often involved in ion exchange processes. Calcium ions typically displace the sodium ions from the clay minerals as the groundwater flows through aquifers. This exchange process causes the loss of calcium concentration in groundwater and enhancement of sodium concentration (Singh et al. 2013a, b; Rawat et al. 2012a, b; Rawat and Tripathi 2015; Tripathi et al. 2016). From table 5(a), average value, positional average and mode of Calcium are 64.31, 52.0 and 32.0 , respectively. The time series (2005-2013) is showing variation in mean, median and mode values (figure 4a). During pre-monsoon $S D$ is high (51.22); thus, it suggests that the sampling year and sampling locations have high variability. It is positively skewed and the curve is platykurtic. Calcium has anti-persistent behaviour (or negative autocorrelation) with EC because of low value of $H$ (0.45 0.50). According to $P I$ value of $\mathrm{Ca}^{2+}(0$, table $5 \mathrm{a}), \mathrm{Ca}^{2+}$ is close to the Brownian motion (unpredictable). From table 5(b), average value, positional average and mode of $\mathrm{Ca}^{2+}$ are 62.74, 48.0 and 24.0, respectively. Similarly, $\mathrm{Ca}^{2+}$ has variation in mean, median and mode values in postmonsoon (2006-2013) (figure 4b). $S D$ value is also high (53.56); thus, the values of $\mathrm{Ca}^{2+}$ are not close to each other. $\mathrm{Ca}^{2+}$ is positively skewed with a platykurtic curve. Again, $\mathrm{Ca}^{2+}$ has anti-persistent behaviour (or negative autocorrelation) with EC $(H=0.47)$. $P I$ value of $\mathrm{Ca}^{2+}$ is 0 (table $4 \mathrm{~b}$ ), therefore $\mathrm{Ca}^{2+}$ is showing the Brownian motion (unpredictable).

\subsection{Magnesium $\left(\mathrm{Mg}^{2+}\right)$}

Calcium and magnesium ions present in groundwater are particularly derived from leaching of limestone, dolomites, gypsum and anhydrites, whereas, the calcium ions are also derived from cation exchange process (Garrels 1976; Singh et al. 2015). The concentration of magnesium ion in this groundwater samples is relatively high when compared to calcium ion concentration and the magnesium concentration is mostly due to weathering of magnesium minerals and leaching of dolomites. The average of $\mathrm{Mg}^{2+}$ (50.26), median (35.00) and mode values (29.00) are different; thus, the curve does not follow normal behaviour. $S D$ is high (70.61), thus the data exhibit normal behaviour. Standard deviation (15.181) is suggesting that the data are not close to each other. The skewness is positive (9.43), 

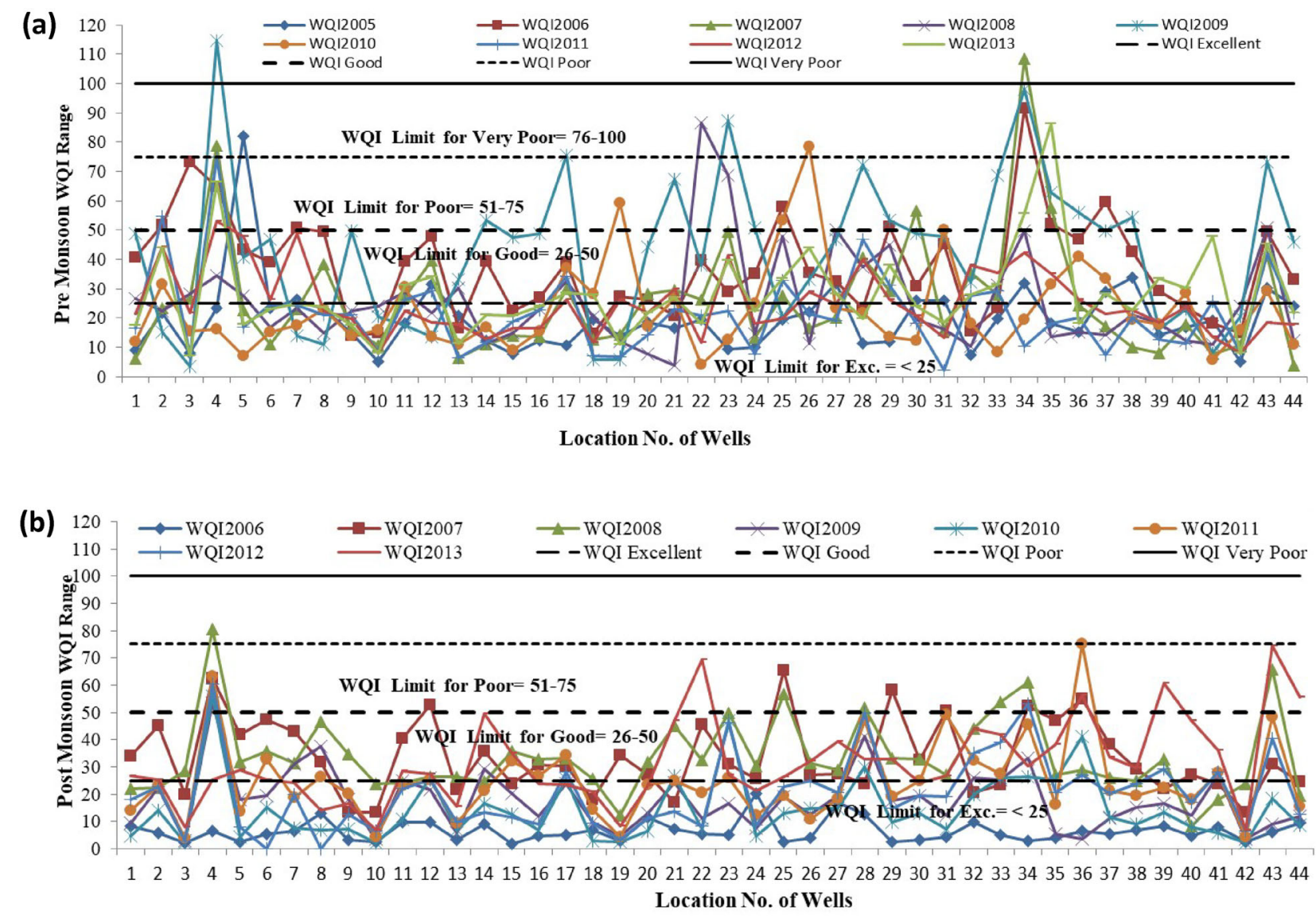

Figure 3. (a) Yearly (2005-2013) value of pre-monsoon water quality index. (b) Yearly (2006-2013) value of post-monsoon water quality index.

thus the curve is moderately symmetrical and platykurtic. $\mathrm{Mg}^{2+}$ has anti-persistent behaviour with EC $(H=0.47 \sim 0.5)$. $P I$ value of Magnesium is $0.1 \sim 0$ (table $5 \mathrm{~b}$ ), $\mathrm{Mg}^{2+}$ shows the Brownian motion (unpredictable) nature. Median (35.00) and mode values (32.00) are close, but average (47.93) is different; thus, the curve does not follow normal behaviour. $S D$ is high (41.70), thus the data exhibit normal behaviour. $S D(41.70)$ suggests that the data are not close to each other. The skewness value $(2.52)$ is positive, thus the curve is moderately symmetrical and platykurtic. $\mathrm{Mg}^{2+}$ has negative autocorrelation with EC $(H=0.48)$ during post-monsoon (2006-2013). $P I$ value of $\mathrm{Mg}$ is 0 (table $5 \mathrm{~b}$ ), $\mathrm{Mg}^{2+}$ has the Brownian motion (unpredictable) nature.

\subsection{Sodium $\left(\mathrm{Na}^{+}\right)$}

The possible source of sodium ions in groundwater is due to dissolution of rock salts and weathering of sodium bearing minerals and weathering of silicate-bearing minerals (Srinivasamoorthy et al. 2008). Average and median values are nearly similar, whereas mode value is different and hence the sodium data show non-normal behaviour. $S D$ value is high (125.89), it exhibits that the sample points are not close to each other and the local geology plays a critical role. The skewness (3.56) suggests that the curve is moderately symmetrical and kurtosis value is quite high (125.89); thus, the nature of curve is platykurtic. $\mathrm{Na}^{+}$has mean reversion behaviour with EC, and $\mathrm{Mg}^{2+}$ during pre-monsoon period (2005-2013) because of low value of $H(0.45(\sim 0.5)$ for $\mathrm{EC}$ and 0.9 for $\mathrm{Mg}^{2+}$ ). From table 5(b), PI value of $\mathrm{Na}^{+}$is 0.1 which indicates $\mathrm{Na}^{+}$towards the Brownian motion (unpredictable) nature. Average, median and mode values are different and thus the data show non-normal behaviour. $S D$ value is high (95.63), which reveals that the groundwater sample points are not close to each other. $S D$ (95.63) suggests that the curve is unsymmetrical and kurtosis value is quite (3.64) high; 
Table 5. Regression equations, coefficient of correlation, Hurst exponent, fractal dimension and predictability index between water parameters during (a) pre-monsoon (2005-2013) and (b) post-monsoon (2006-2013).

\begin{tabular}{|c|c|c|c|c|c|c|c|c|}
\hline $\mathrm{Y}$ & $\begin{array}{l}\text { Parameters } \\
\text { (X) }\end{array}$ & $\begin{array}{c}\text { Regression } \\
\text { equation }\end{array}$ & $r^{2}$ & $r$ & $m_{y x}$ & $H$ & $D$ & $P I$ \\
\hline \multicolumn{9}{|c|}{ (a) Pre-monsoon (2005-2013) } \\
\hline $\mathrm{Ca}^{2+}$ & $\mathrm{EC}$ & $0.03 * \mathrm{X}+23.52$ & 0.42 & 0.648 & 0.03 & 0.49 & 1.52 & 0.0 \\
\hline $\mathrm{Mg}^{2+}$ & $\mathrm{EC}$ & $0.057 * \mathrm{X}-25.87$ & 0.771 & 0.878 & 0.06 & 0.47 & 1.53 & 0.1 \\
\hline \multirow[t]{2}{*}{$\mathrm{Na}^{+}$} & $\mathrm{EC}$ & $0.103 * \mathrm{X}+3.666$ & 0.783 & 0.885 & 0.10 & 0.45 & 1.55 & 0.1 \\
\hline & $\mathrm{Mg}^{2+}$ & $1.189 * X+80.77$ & 0.44 & 0.667 & 1.19 & 0.09 & 1.91 & 0.8 \\
\hline \multirow[t]{4}{*}{$\mathrm{Cl}^{-}$} & $\mathrm{Mg}^{2+}$ & $4.334 * \mathrm{X}+18.23$ & 0.87 & 0.933 & 4.33 & 1.67 & 0.33 & 2.3 \\
\hline & $\mathrm{EC}$ & $0.289 * \mathrm{X}-146.7$ & 0.903 & 0.95 & 0.29 & 0.36 & 1.64 & 0.3 \\
\hline & $\mathrm{Na}^{+}$ & $2.061 * X-53.56$ & 0.625 & 0.791 & 2.06 & 0.53 & 1.47 & 0.1 \\
\hline & $\mathrm{Ca}^{2+}$ & $3.671 * \mathrm{X}-0.031$ & 0.328 & 0.573 & 3.67 & 1.34 & 0.66 & 1.7 \\
\hline \multirow[t]{3}{*}{$\mathrm{SO}_{4}^{2-}$} & $\mathrm{Ca}^{2+}$ & $1.792 * \mathrm{X}-22.69$ & 0.35 & 0.592 & 1.79 & 0.40 & 1.60 & 0.2 \\
\hline & $\mathrm{Na}^{+}$ & $0.829 * \mathrm{X}-23.99$ & 0.453 & 0.674 & 0.83 & 0.09 & 1.91 & 0.8 \\
\hline & $\mathrm{EC}$ & $0.1 * \mathrm{X}-39.7$ & 0.483 & 0.695 & 0.10 & 0.45 & 1.55 & 0.1 \\
\hline \multirow[t]{6}{*}{ TDS } & $\mathrm{Mg}^{2+}$ & $8.09 * \mathrm{X}+376.2$ & 0.764 & 0.874 & 8.09 & 3.55 & -1.55 & 6.1 \\
\hline & $\mathrm{Cl}^{-}$ & $1.87 * \mathrm{X}+341.2$ & 0.882 & 0.939 & 1.87 & 0.44 & 1.57 & 0.1 \\
\hline & $\mathrm{Na}^{+}$ & $4.669 * \mathrm{X}+126.6$ & 0.809 & 0.9 & 4.67 & 1.83 & 0.17 & 2.7 \\
\hline & $\mathrm{SO}_{4}^{2-}$ & $3.106 * \mathrm{X}+495.3$ & 0.542 & 0.737 & 3.11 & 1.05 & 0.95 & 1.1 \\
\hline & $\mathrm{Ca}^{2+}$ & $8.168 * \mathrm{X}+257.6$ & 0.41 & 0.64 & 8.17 & 3.58 & -1.58 & 6.2 \\
\hline & $\mathrm{EC}$ & $0.601 * \mathrm{X}-13.4$ & 0.984 & 0.992 & 0.60 & 0.20 & 1.80 & 0.6 \\
\hline \multicolumn{9}{|c|}{ (b) Post-monsoon (2006-2013) } \\
\hline $\mathrm{Ca}^{2+}$ & $\mathrm{EC}$ & $0.047 * X+3.102$ & 0.598 & 0.774 & 0.047 & 0.48 & 1.52 & 0.0 \\
\hline $\mathrm{Mg}^{2+}$ & $\mathrm{EC}$ & $0.04 * X-2.02$ & 0.693 & 0.832 & 0.04 & 0.48 & 1.52 & 0.0 \\
\hline $\mathrm{Na}^{+}$ & $\mathrm{EC}$ & $0.09 * \mathrm{X}+12.98$ & 0.668 & 0.818 & 0.09 & 0.46 & 1.55 & 0.1 \\
\hline \multirow[t]{4}{*}{$\mathrm{Cl}^{-}$} & $\mathrm{Ca}^{2+}$ & $3.428 * \mathrm{X}+8.404$ & 0.568 & 0.754 & 3.428 & 1.21 & 0.79 & 1.4 \\
\hline & $\mathrm{Mg}^{2+}$ & $5.003 * \mathrm{X}-16.28$ & 0.733 & 0.754 & 5.003 & 2.00 & 0.00 & 3.0 \\
\hline & $\mathrm{EC}$ & $0.26 * \mathrm{X}-105$ & 0.878 & 0.937 & 0.26 & 0.37 & 1.63 & 0.3 \\
\hline & $\mathrm{Na}^{+}$ & $1.823 * \mathrm{X}-5.363$ & 0.512 & 0.716 & 1.823 & 0.41 & 1.59 & 0.2 \\
\hline $\mathrm{HCO}_{3}^{-}$ & $\mathrm{Na}^{+}$ & $0.48 * X+184.5$ & 0.142 & 0.611 & 0.48 & 0.26 & 1.74 & 0.5 \\
\hline $\mathrm{SO}_{4}^{2-}$ & $\mathrm{EC}$ & $0.087 * X-33.41$ & 0.443 & 0.666 & 0.087 & 0.46 & 1.54 & 0.1 \\
\hline \multirow[t]{6}{*}{ TDS } & $\mathrm{Na}^{+}$ & $4.296 * \mathrm{X}+185.7$ & 0.719 & 0.848 & 4.296 & 1.65 & 0.35 & 2.3 \\
\hline & $\mathrm{Cl}^{-}$ & $1.82 * \mathrm{X}+318.2$ & 0.837 & 0.915 & 1.82 & 0.41 & 1.59 & 0.2 \\
\hline & $\mathrm{SO}_{4}^{2-}$ & $2.99 * \mathrm{X} 4+98.4$ & 0.496 & 0.705 & 2.99 & 1.00 & 1.01 & 1.0 \\
\hline & $\mathrm{EC}$ & $0.553 * \mathrm{X}+36.26$ & 0.976 & 0.988 & 0.553 & 0.22 & 1.78 & 0.6 \\
\hline & $\mathrm{Ca}^{2+}$ & $6.942 * \mathrm{X}+289.6$ & 0.589 & 0.768 & 6.942 & 2.97 & -0.97 & 4.9 \\
\hline & $\mathrm{Mg}^{2+}$ & $9.308 * \mathrm{X}+279$ & 0.642 & 0.801 & 9.308 & 4.15 & -2.15 & 7.3 \\
\hline
\end{tabular}

thus, the nature of curve is platykurtic. $\mathrm{Na}^{+}$has anti-persistent behaviour with EC during pre-monsoon period (2006-2013) and towards the unpredictable nature.

\subsection{Chloride $\left(\mathrm{Cl}^{-}\right)$}

The natural process such as weathering, dissolution of salt deposits, and irrigation drainage return flow are responsible for chloride content in the groundwater. Average (236.10), median (149.0) and mode (50.0) values are not equal, and thus the data show abnormal behaviour. $S D$ value (328.05) shows that the sample points are not close to each other. Skewness value (7.28) suggests that the curve is unsymmetrical and the high kurtosis value also defines nature of curve as platykurtic. Chloride has persistent behaviour with EC but with $\mathrm{Mg}^{2+}, \mathrm{Na}^{+}$ and $\mathrm{Ca}^{2+}$ having anti-persistent behaviour due to greater value of $H(1.67,0.53$ and 1.34 , respectively) from 0.5 during pre-monsoon series from 2005 to 2013 . According to $P I$ value of $\mathrm{Na}^{+}(0.1 \sim 0$, table $5 \mathrm{a}), \mathrm{Na}$ is towards the Brownian motion (unpredictable). 

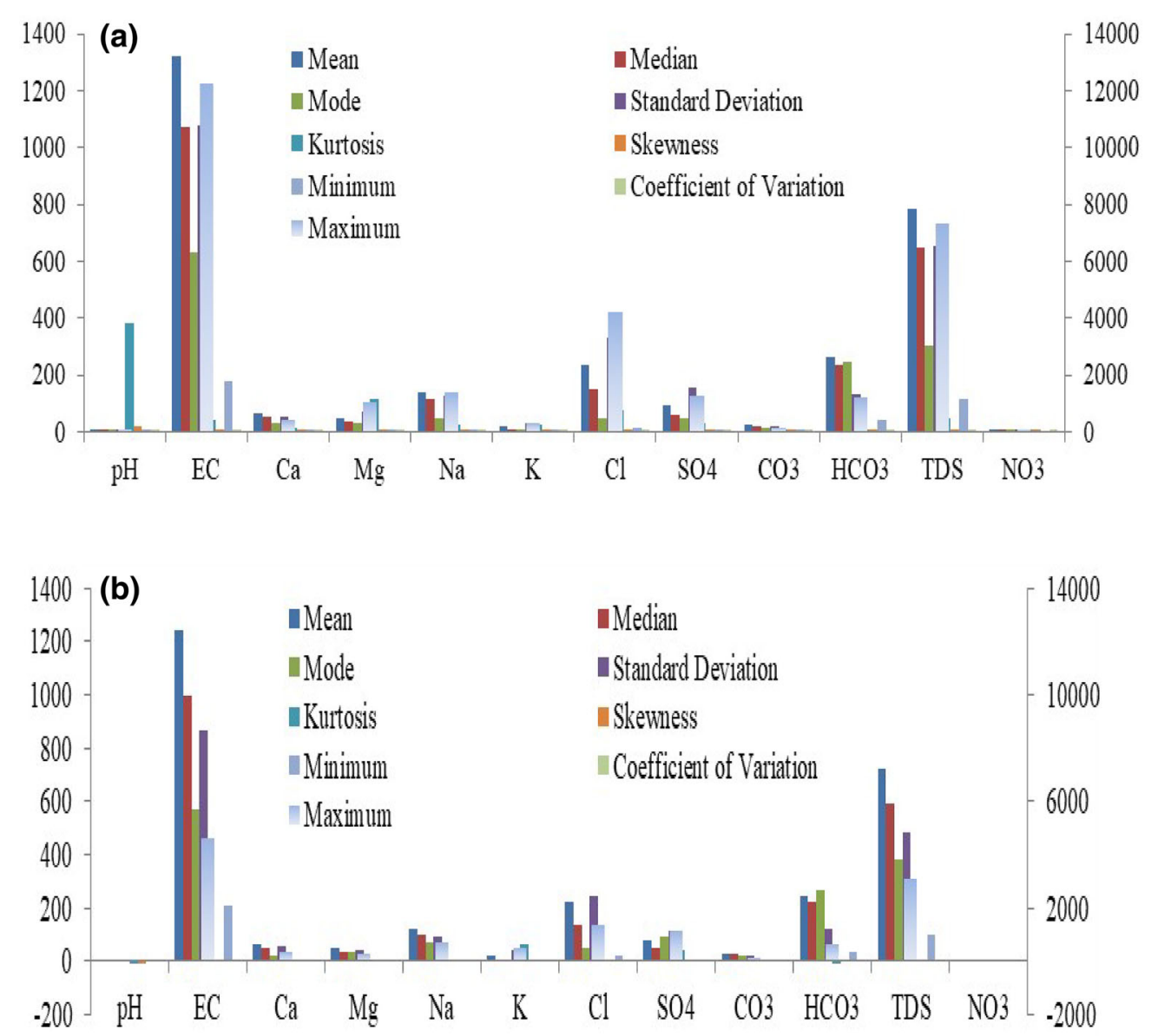

Figure 4. Graphical representation of statistical analysis of (a) pre-monsoon water parameters (2005-2016) and (b) postmonsoon water parameters (2006-2016).

The average value, positional average and mode of $\mathrm{Cl}^{-}$were 223.54, 135.0 and 53.0, respectively. Figure 3(b) is showing much variation in mean, median and mode values during post-monsoon data series (2006-2013), thus datasets have abnormal behaviour. $S D$ value of $\mathrm{Cl}^{-}$(during post-monsoon) shows that the sample points (or wells) are not close to each other. Less skewness value (2.46) suggests that the curve is moderately symmetrical and kurtosis value is revealing curve is platykurtic. Chloride has anti-persistent behaviour with EC and $\mathrm{Na}^{+}$(table 5b), but with $\mathrm{Ca}^{2+}$ and $\mathrm{Mg}$ it has persistent (a positive autocorrelation) behaviour due to greater value of $H$ (1.21 and 2.00, table 5b) during post-monsoon series from 2005 to 2013.

\subsection{Sulfate $\left(\mathrm{SO}_{4}^{2-}\right)$}

Sulfate ion concentrations are probably derived from weathering of sulfate and gypsum-bearing sedimentary rocks (Elango et al. 2003; Jeevanandam et al. 2006). Average value, positional average and mode of $\mathrm{SO}_{4}^{2-}$ were 92.55, 57.00 and 48.00, respectively. There is variation in average, median and mode values and thus the data show unusual behaviour. $S D$ value (154.96) exhibits that the observation values of $\mathrm{SO}_{4}^{2-}$ from wells (or sample points) are not close to each other. Skewness value (5.45) suggests that the curve is towards the symmetrical and kurtosis value is higher (32.69); thus, the curve is platykurtic. $\mathrm{SO}_{4}^{2-}$ has anti-persistent behaviour with $\mathrm{Ca}^{2+}, \mathrm{Na}^{+}$and EC during premonsoon. Average (76.04), median (49.50) and mode (96.00) values are not equal, and thus the data does not show normal behaviour. $S D$ value (114.30) shows that the sample points are not close to each other. Skewness value (6.05) suggests that the curve is unsymmetrical and the high kurtosis value explains the nature of curve to be platykurtic. $\mathrm{SO}_{4}^{2-}$ has anti-persistent behaviour with EC because of less value of $H(0.46)$ during 
post-monsoon series from 2005 to 2013 . According to $P I$ value of $\mathrm{SO}_{4}^{2-}(0.1 \sim 0$, table $5 \mathrm{a}), \mathrm{SO}_{4}^{2-}$ moves toward the Brownian motion (unpredictable).

\subsection{Total dissolved solids (TDS)}

The total of major cations and anions present in groundwater represents the total dissolved solids (Rawat et al. 2012b; Singh et al. 2013a, b; Rawat and Tripathi 2015; Jacintha et al. 2016; Tripathi et al. 2016). The concentration of ions in groundwater depends on many factors and processes that occur in the aquifer system (Singh et al. 2009). The identification of geochemical processes is investigated by the study of concentrations of various major ions present in groundwater. It is a general indicator of water quality generally used to understand the amount of contaminant present in the groundwater (Jeelani et al. 2014). Mean (782.90), median (648.00) and mode (304.00) values are different; thus, the curve does not follow normal behaviour. $S D$ value is high (653.39), thus the values of TDS are not close to each other. It is positively skewed and the curve is platykurtic. TDS has persistent behaviour with $\mathrm{Mg}^{2+}, \mathrm{Na}^{+}$, $\mathrm{SO}_{4}^{2-}$ and EC, and anti-persistent behaviour with $\mathrm{Ca}^{2+}$ during pre-monsoon (2005-2013). During post-monsoon (2006-2013), average value (725.24), positional average (593.00) and mode (380.00) is not in close ranges, much variation exists among them, thus the data show unusual behaviour. $S D$ value (484.41) exhibits that the observation value of TDS from wells (or sample points) are not close to each other. Skewness value (1.86) suggests that the curve is close to symmetrical and kurtosis value is also low (4.18); thus, the curve is platykurtic. TDS has anti-persistent behaviour with $\mathrm{Cl}^{-}$, and EC (towards unpredicted nature) and persistent behaviour with $\mathrm{Na}^{+}, \mathrm{SO}_{4}^{2-}, \mathrm{Ca}^{2+}$ and $\mathrm{Mg}^{2+}$ during post-monsoon time period (2006-2013).

\subsection{Bicarbonate $\left(\mathrm{HCO}_{3}^{-}\right)$}

For irrigation purposes, the suitability of groundwater is controlled by the quantity of bicarbonate and carbonate present in water in excess of alkaline earths $\left(\mathrm{Ca}^{2+}+\mathrm{Mg}^{2+}\right)(\mathrm{Pal}$ and Poonia 1979). When the total of carbonates and bicarbonates is in excess of calcium and magnesium, there may be possibility of complete precipitation of $\mathrm{Ca}^{2+}$ and $\mathrm{Mg}^{2+}$ ions (Rawat et al. 2012b; Singh et al. 2013a, b, 2015; Tripathi et al. 2016). The availability of carbonate minerals in the recharge areas and silicate weathering are the main factors, which lead to increase of carbonates and bicarbonate concentration in the groundwater (Elango et al. 2003). Average (244.94), median (226.00) and mode (268.00) values are almost in the same range, and thus the data show normal behaviour. Standard deviation value $(122.0=49.8 \%$ of average value) explains that the sample data are not spread. The curve is skewed and platykurtic. $\mathrm{HCO}_{3}^{-}$has anti-persistence behaviour with $\mathrm{Na}^{+}$ due to $H(0.26)$ value $<0.5$ during post-monsoon (table 5b). But during pre-monsoon, $\mathrm{HCO}_{3}^{-}$has less significant correlation coefficient $(r)$ with TDS, therefore, $\mathrm{HCO}_{3}^{-}$has no regression equation with TDS.

\section{Conclusion}

Weathering processes and anthropogenic inputs are the two main contributors for changing the geochemical composition of the groundwater. The statistical analysis result highlights that all groundwater parameters are having platykurtic curve. The Brownian time series behaviour exists for $\mathrm{Ca}^{2+}$ with EC; $\mathrm{Mg}^{2+}$ with $\mathrm{EC} ; \mathrm{SO}_{4}^{2-}$ with EC and TDS with EC which continues during preand post-monsoon from 2005 to 2013. The persistent behaviour (a positive autocorrelation) exists between $\mathrm{Cl}^{-}$with $\mathrm{Mg}^{2+}, \mathrm{Cl}^{-}$with $\mathrm{Ca}^{2+}$, TDS with $\mathrm{Na}^{+}$, TDS with $\mathrm{SO}_{4}^{2-}$ and TDS with $\mathrm{Ca}^{2+}$ in the times series of hydrogeochemical parameters of groundwater in pre- and post-monsoon because of higher value of $H(>1)$. The antipersistent behaviour (a negative autocorrelation) exists of $\mathrm{Cl}^{-}$with EC, TDS with EC during pre- and post-monsoon due to low value of $H$. The average of hydrogeochemical parameters is close to the prescribed WHO (2006) standard for the period (2005-2013). The WQI values of pre- and post-monsoon of 44 monitored wells show that majority of sites fall in the category of suitable, polluted and moderately polluted. Few sites also fall in the category of highly polluted and unfit in the pre-monsoon. Whereas, there is only one site in the post-monsoon season which falls in the category of highly polluted in the year 2008. WQI patterns fluctuate for each year. The water of the post-monsoon season is less polluted as compared to pre-monsoon season and this is attributed to recharge of groundwater table after rainfall. For individual well spread throughout the study area land use subcontinent, 
our studies quantify the inconsistency and discrepancy between predictability of groundwater physicochemical parameter vs. any other groundwater physicochemical parameter using regression equation, $H, D$ and $P I$ analysis. This analysis reveals that some groundwater physicochemical parameter of the study area can predict other groundwater physicochemical parameter with strong $\mathrm{r}$ and $r^{2}$. Groundwater contamination is very complex due to natural and anthropogenic phenomena. However, in this work, the complexity has been studied from a different viewpoint using statistical tests $m_{x y}, r, r^{2}, H, D$, and $P I$. The groundwater quality analyses indicate that the local geology, climate plays a dominant role in controlling the groundwater chemistry and the dissolution of carbonate rocks and silicate weathering and ion exchange process controls the distribution of major ions in the water.

\section{Acknowledgements}

We would like to thank Shri K Santanam (Ex Joint Director (Geology), Water Resource Division, PWD, Chennai) for useful discussions and providing groundwater quality datasets (2005-2013) for analysis and paper work, and Editor-in-Chief of the journal.

\section{References}

Amin A, Fazal S, Mujtaba A and Singh S K 2014 Effects of land transformation on water quality of Dal Lake, Srinagar, India; J. Indian Soc. Remote Sens. 42(1) 119-128, https://doi.org/10.1007/s12524-013-0297-9.

Avvannavar S M and Shrihari S 2007 Evaluation of water quality index for drinking purposes for river Netravathi, Mangalore, South India; Environ. Monit. Assess. 143(13) 279-290, https://doi.org/10.1007/s10661-007-9977-7.

Balakrishnan T 2007 District Ground Water Brochure, Kancheepuram District, Government of India, Ministry of Water Resources, Central Ground Water Board, South Eastern Coastal Region, Chennai. (cgwb.gov.in/districtprofile/tamilnadu/kancheepuram.pdf), pp. 1-22.

Bordalo A A, Nilsumranchi W and Chalermwat K 2001 Water quality and uses of the Bangpakong River (Eastern Thailand); Water Res. 35 3535-3642.

Brown R M, McClelland N I, Deininger R A and O'Connor MF 1972 Water Quality Index-Crashing, the Psychological Barrier; Proc. 6th Annual Conference, Advances in Water Pollution Research, pp. 787-794, https://doi.org/ 10.1016/b978-0-08-017005-3.50067-0.

Brown R M, McClelland N I, Deininger R A and Tozer R 1970 A Water Quality Index - Do we dare? Water and Sewage Works, October.
Carlson E and Ecker M D 2002 A statistical examination of water quality in two Iowa Lakes; Am. J. Undergrad. Res. 1(2) 31-45.

Chatterjee C and Raziuddin M 2002 Determination of water quality index (WQI) of a degraded river in Asanol Industrial area, Raniganj, Burdwan, West Bengal; Nature Environ. Pollut. Tech. 1(2) 181-189.

Chenini I, Ben Mammou A and Turki M M 2008 Groundwater resources of a multi-layered aquiferous system in arid area: Data analysis and water budgeting; Int. J. Environ. Sci. Technol. 5(3) 361-374.

Chenini I and Khemiri S 2009 Evaluation of ground water quality using multiple linear regression and structural equation modelling; Int. J. Environ. Sci. Technol. 6(3) 509-519.

Couillard D and Lefebvre Y 1985 Analysis of water quality indexes; J. Env. Manag. 21 161-179.

Elango L, Kannan R and Senthil Kumar M 2003 Major ion chemistry and identification of hydrogeochemical processes of groundwater in a part of Kancheepuram District, Tamil Nadu, India; Environ. Geosci. 10 157-166.

Garrels R M 1976 A survey of low temperature water mineral relations; In: Interpretation of Environmental Isotope and Hydrogeochemical Data in Groundwater Hydrology, International Atomic Energy Agency, Vienna, pp. 6584.

Gautam S K, Maharana C, Sharma D, Singh A K, Tripathi J K and Singh S K 2015 Evaluation of groundwater quality in the Chotanagpur plateau region of the Subarnarekha river basin, Jharkhand State, India; Sustain. Water Qual. Ecol. 6 57-74, https://doi.org/10.1016/j.swaqe.2015.06. 001.

House M A and Newsome D H 1989 Water quality indices for the management of surface water quality; Water Sci. Technol. 21 1137-1148.

Hsui A T, Rust K A and Klein G D 1993 A fractal analysis of Quaternary, Cenozoic-Mesozoic, and Late Pennsylvanian sea level changes; J. Geophys. Res. 98B 21,963-21,967.

Jacintha T G A, Rawat K S, Mishra A and Singh S K 2016 Hydrogeochemical characterization of groundwater of peninsular Indian region using multivariate statistical techniques; Appl. Water Sci., https://doi.org/10.1007/ s13201-016-0400-9.

Jeelani G H, Shah R A and Hussain A 2014 Hydrogeochemical assessment of groundwater in Kashmir Valley, India; J. Earth Syst. Sci. 123(5) 1031-1043, https://doi.org/10. 1007/s12040-014-0446-8.

Jeevanandam M, Kannan R, Srinivasalu S and Rammohan V 2006 Hydrogeochemistry and groundwater quality assessment of lower part of the Ponnaiyar River Basin, Cuddalore district, south India; Environ. Monit. Assess. 132 263-274, https://doi.org/10.1007/s10661-006-9532-y.

Joarder M A M, Raihan F, Alam J B and Hasanuzzaman S 2008 Regression analysis of ground water quality data of Sunamganj district, Bangladesh; Int. J. Environ. Res. 2(3) 291-296.

Kaurish F and Younos T 2007 Developing a standardized water quality index for evaluating surface water quality; J. Am. Water Resour. Assoc. 23 533-545.

Korashey R 2009 Using regression analysis to estimate water quality constituents in Bahr El Baqar drain; J. Appl. Sci. Res. 5(8) 1067-1076. 
Kumar N and Sinha D K 2010 Drinking water quality management through correlation studies among various physico-chemical parameters: A case study; Int. J. Environ. Sci. 1(2) 253-259.

Liou S M, Lo S L and Wang S H 2004 A generalised water quality index for Taiwan; Environ. Monit. Assess. 96 3532 .

Mousavi M, Kiani S, Lotfi S, Naeemi N and Honarmand M 2008 Transient and spatial modelling and simulation of polybrominated diphenyl ethers reaction and transport in air, water and soil; Int. J. Environ. Sci. Technol. 5(3) 323-330.

Nemčić-Jurec J, Singh S K, Jazbec A, Gautam S K and Kovac I 2017 Hydrochemical investigations of groundwater quality for drinking and irrigational purposes: Two case studies of Koprivnica-Krizěvci County (Croatia) and district Allahabad (India); Sustain. Water Resour. Manag., https://doi.org/10.1007/s40899-017-0200-x.

Oişte A M 2014 Groundwater quality assessment in urban environment; Int. J. Environ. Sci. Technol. 11(7) 20952102, https://doi.org/10.1007/s13762-013-0477-8.

Parmar K S and Bhardwaj R 2013 Water quality index and fractal dimension analysis of water parameters; Int. J. Environ. Sci. Technol. 10 151-164, https://doi.org/10. 1007/s13762-012-0086-y.

Pesce S F and Wunderlin D A 2000 Use of water quality indices to verify the impact of Cordoba City (Argentina) on Suquia River; Water Res. 34 2915-2926.

Psargaonkar A, Gupta A and Devotta S 2008 Multivariate analysis of ground water resources in Ganga-Yamuna Basin (India); J. Environ. Sci. Eng. 50(3) 215-222.

Rangarajan G 1997 A climate predictability index and its applications; Geophys. Res. Lett. 24(10) 1239-1242.

Rangarajan G and Sant D A 2004 Fractal dimensional analysis of Indian climatic dynamics; Chaos, Solitons Fractals $19285-291$.

Rawat K S and Tripathi V K 2015 Hydro-chemical survey and quantifying spatial variations of Groundwater quality in Dwarka, Sub-city of Delhi, India; The Institution of Engineers (India), https://doi.org/10.1007/ s40030-015-0116-0.

Rawat K S, Mishra A K and Sehgal V K 2012a Identification of geospatial variability of fluoride contamination in ground water of Mathura District, Uttar Pradesh, India; J. Appl. Natural Sci. 4(1) 117-122.

Rawat K S, Mishra A K, Sehgal V K and Tripathi V K 2012b Spatial variability of ground water quality in Mathura District (Uttar Pradesh, India) with geostatistical method; Int. J. Remote Sens. Appl. 2(1) 1-9.

Rawat K S, Mishra A K and Singh S K 2017a Mapping of groundwater quality using normalized Difference Dispersal Index of Dwarka subcity at Delhi National Capital of India; ISH J. Hydraul. Eng. 23(3) 229-240, https://doi. org/10.1080/09715010.2016.1277795.

Rawat K S, Tripathi V K and Singh SK 2017b Groundwater quality evaluation using numerical indices: A case study (Delhi, India); Sustain. Water Resour. Manag.,https:// doi.org/10.1007/s40899-017-0181-9.

Sánchez E, Colmenarejo M F, Vicente J, Rubio A, García M G, Travieso L and Borja R 2007 Use of the water quality index and dissolved oxygen deficit as simple indicators of watersheds pollution; Ecological Indicators 7 315-328, https://doi.org/10.1016/j.ecolind.2006.02.005.

Sargaonkar A and Deshpande V 2003 Development of an overall index of pollution for surface water based on a general classification scheme in Indian context; Environ. Monit. Assess. 89 43-67.

Singh S, Singh C, Kumar K, Gupta R and Mukherjee S 2009 Spatial-temporal monitoring of groundwater using multivariate statistical techniques in Bareilly district of Uttar Pradesh, India; J. Hydrol. Hydromech. 57(1) 45-54.

Singh S K, Singh C K and Mukherjee S 2010 Impact of landuse and land-cover change on groundwater quality in the Lower Shiwalik hills: A remote sensing and GIS based approach; Cent. Eur. J. Geosci. 2 124-131, https://doi. org/10.2478/v10085-010-0003-x.

Singh S K, Srivastava P K and Pandey A C 2013a Fluoride contamination mapping of groundwater in northern India integrated with geochemical indicators and GIS; Water Sci. Technol. Water Supply 13(6) 1513-1523, https://doi. org/10.2166/ws.2013.160.

Singh S K, Srivastava P K and Pandey A C 2013b Integrated assessment of groundwater influenced by a confluence river system: Concurrence with remote sensing and geochemical modeling; Water Resour. Manag. 27 4291-4313, https://doi.org/10.1007/s11269-013-0408-y.

Singh S K, Srivastava P K, Singh D, Han D, Gautam S K and Pandey A C 2015 Modeling groundwater quality over a humid subtropical region using numerical indices, earth observation datasets, and X-ray diffraction technique: A case study of Allahabad district, India; Environ. Geochem. Health 37(1) 157-180, https://doi.org/10. 1007/s10653-014-9638-z.

Singh S K, Singh P and Gautam S K 2016 Appraisal of urban lake water quality through numerical index, multivariate statistics and earth observation data sets; Int. J. Sci. Tech. 3(2) 445-456, https://doi.org/10.1007/ s13762-015-0850-x.

Smith D G 1989 A new form of water quality index for rivers and streams; Water Sci. Technol. 21 123-127.

Snow J 1856 Cholera and the water supply in the south districts of London in 1854; T. Richards.

Srinivasamoorthy K, Chidambaram S, Prasanna M V, Vasanthavihar M, Peter J and Anandhan P 2008 Identification of major sources controlling groundwater chemistry from a hard rock terrain - A case study from Mettur taluk, Salem district, Tamil Nadu, India; J. Earth Syst. Sci. 117 49-58, https://doi.org/10.1007/s12040-008-0012-3.

Stambuk-Giljanovik N 2003 Comparison of Dalmation water evaluation indices; Water Environ. Res. 75(5) 388-405.

Swamee P K and Tyagi A 2000 Describing water quality with aggregate index; J. Environ. Eng. 126 451-455.

Thakur J K, Diwakar J and Singh S K 2015. Hydrogeochemical evaluation of groundwater of Bhaktapur Municipality, Nepal; Environ. Earth Sci. 74(6) 4973-4988, https://doi. org/10.1007/s12665-015-4514-4.

Tripathi V K, Shukla S K and Rawat K S 2016 Calcium and chloride variability assessment in the Semi-arid region A case study; Int. J. Sci. Environ. Tech. 5(5) $2877-$ 2884 .

Tsegaye T, Sheppard D, Islam K R, Johnson A, Tadesse W, Atalay A and Marzen L 2006 Development of chemical 
index as a measure of in-stream water quality in response to land-use and land cover changes; Water, Air Soil Pollut. 174 161-179.

Vasanthavigar M, Srinivasamoorthy K, Vijayaragavan K, Ganthi R R, Chidambaram S and Anandhan $\mathrm{P}$ et al. 2010 Application of water quality index for groundwater quality assessment: Thirumanimuttar sub-basin, Tamilnadu, India; Environ. Monit. Assess. 171(1-4) 595609.

Vassilis Z, Antonopoulos M and Mitsiou A K 2001 Statistical and trend analysis of water quality and quantity data for the Strymon River in Greece; Hydrol. Earth Syst. Sci. 5(4) 679-691.

Vidyalakshmi R, Brindha B, Roosvelt P S B, Rajakumar S and Devi M P 2013 Determination of land use stress on drinking water quality in Tiruchirappalli, India using derived indices; Water Quality, Exposure and Health 5(1) $11-29$.

World Health Organization (WHO) 2006 Guidelines for drinking-water quality; Recommendations, vol. 1, 3rd edn, World Health Organization, Geneva, 595p., ISBN 9241546964 .

Corresponding editor: RAJIB MAITY 